\title{
Paleoceanographic changes in the Northern East China Sea during the last 400 kyr as inferred from radiolarian assemblages (IODP Site U1429)
}

\author{
Kenji M. Matsuzaki ${ }^{1,2^{*}}$ (D, Takuya Itaki $^{3}$ and Ryuji Tada ${ }^{1}$
}

\begin{abstract}
The East China Sea (ECS) is a shallow marginal sea that is sensitive to glacio-eustatic sea-level changes and is influenced by warm oligotrophic water of the Kuroshio Current (KC), the nutrient-rich Taiwan Warm Current, and freshwater discharges from rivers in southern China during the East Asian summer monsoon season. In this area, local paleoceanographic changes for times prior to 40 ka remain poorly studied because of high sediment accumulation rates on the seafloor. During Integrated Ocean Drilling Program Expedition 346, long sediment cores representing the last $400 \mathrm{kyr}$ were retrieved from the northern part of the ECS (Site U1429). In these cores, radiolarians are abundant and well-preserved, thus using the ecological properties of radiolarians, we analyzed how glacio-eustatic sea-level variations have influenced the paleoceanography of the ECS over the last $400 \mathrm{kyr}$, with a focus on changes in water properties at intermediate depths. Additionally, the summer sea surface temperature (SST) and intermediate water temperature at about $500 \mathrm{~m}$ were quantified by means of data on selected radiolarian species. The KC influenced the shallow water at Site U1429 during each interglacial period over the last $400 \mathrm{kyr}$ (marine isotope stages [MISs] 1, 5, 7, 9, and 11), causing a high summer SST (about $27^{\circ} \mathrm{C}$ ), although inflow of the KC into the ECS was probably delayed until after the sea-level maximum of interglacial MIS 1 and MIS 5. During this lag time, ECS shelf water was the dominant influence on the system. During glacial periods (MISs 2-4, 6, and 10), our data suggest that coastal conditions prevailed, probably because of a sea-level drop of more than $90 \mathrm{~m}$. At these times, the summer SST was colder, ca. $20^{\circ} \mathrm{C}$. Changes in the relative abundance of Cycladophora davisiana indicate that the most significant changes in the bottom water occurred during MIS 6, when the bottom water likely became poorer in oxygen. An increase in the shallow-water primary productivity during MIS 7 and MIS 6 was probably the key factor causing the oxygen-poor conditions.
\end{abstract}

Keywords: East China Sea, Kuroshio current, Changjiang River, Sea-level variations, Primary productivity, Bottom water, Oxygen-poor seawater, Radiolarians

\section{Introduction}

The East China Sea (ECS) is a marginal sea of the Northwest Pacific, and 70\% of this sea lies over a continental shelf. The ECS is influenced by warm oligotrophic water of the Kuroshio Current (KC), the nutrient-rich Taiwan Warm Current (TWC), and discharges of freshwater from the Changjiang River (Chen et al. 1994). The

\footnotetext{
* Correspondence: km.matsuzaki@aori.u-tokyo.ac.jp

${ }^{1}$ Department of Earth and Planetary Science, Graduate School of Science,

The University of Tokyo, 7-3-1, Hongo, Bunkyo-ku, Tokyo 113-0033, Japan

${ }^{2}$ Present address: Atmosphere and Ocean Research Institute, The University

of Tokyo, 5-1-5 Kashiwanoha, Kashiwa, Chiba 277-8564, Japan

Full list of author information is available at the end of the article
}

volume of discharge from the Changiiang River increases during the East Asian summer monsoon (EASM), which causes high precipitation in southern China during summer and thus triggers greater freshwater discharges from the Changjiang River (e.g., Ichikawa and Beardsley 2002; Kagimoto and Yamagata 1997; Tada et al. 2016). Thus, the Changjiang River supplies a huge amount of freshwater into the northern ECS, and it mixes with the saline ambient water influenced by the TWC and $\mathrm{KC}$ to form the ECS continental shelf water (CSW; e.g., Ichikawa and Beardsley 2002). Moreover, upwelling of the $\mathrm{KC}$ subsurface water and the North Pacific Intermediate 
Water (NPIW) at the slope of the ECS continental shelf contributes to the availability of a large number of nutrients in the shallow water of the ECS (e.g., Chen 1996; Chen and Wang 1999; Ito et al. 1994; Matsuno et al. 2009).

Global climate during the Pleistocene is known to have been characterized by a series of alternating warm and cold (glacial and interglacial) periods, which were regulated and paced by the Milankovitch cycles, and signals from these cycles are well-recorded in the oxygen isotope ratio $\left(\delta^{18} \mathrm{O}\right)$ of benthic foraminifera (e.g., Berger and Jansen 1994; Hays et al. 1976; Lisiecki and Raymo 2005; Elderfield et al. 2012). Recently, Elderfield et al. (2012) tried to separate the effects of temperature and global ice volume on the deep-ocean foraminifera $\delta^{18} \mathrm{O}$. The amplitude of the glacio-eustatic sea-level change $(120 \mathrm{~m}$, e.g., Yokoyama et al. 2001; Xie et al. 1995) are almost similar in glacial-interglacial cycles for the past $700 \mathrm{kyr}$, except for the MIS7/8 (300 ka). The Pleistocene is also known for being influenced by millennial-scale climatic instability, the so-called Dansgaard-Oeschger (D-O) events, which are abrupt climatic changes caused by periodic collapses of continental ice sheets in the Northern Hemisphere and reductions in North Atlantic Deep Water formation (e.g., Bond et al. 1993; Dansgaard et al. 1993; Hodell and Channell 2016; Tada et al. 2018; Wary et al. 2016). These events also caused variations in sea level.

Previous studies have shown that the ECS is sensitive to the glacio-eustatic sea-level changes caused by the glacial/ interglacial cycles because most of its surface water lies above a continental shelf $(<200 \mathrm{~m})$. Indeed, during glacial periods over the last $40 \mathrm{kyr}$, about one-half of the ECS continental shelf emerged and the mouth of the Changjiang River likely migrated southeastward toward the Okinawa Trough because of a sea-level drop of ca. $130 \mathrm{~m}$ (e.g., Ijiri et al. 2005; Kawahata and Ohshima 2004; Tada et al. 2015; Xie et al. 1995). Such changes in the ECS landscape probably caused drastic changes in the local and regional paleoceanography. Several micropaleontological and geochemical studies have reconstructed changes in local hydrography of the shallow water over the past 40 kyr (e.g., Ijiri et al. 2005; Kawahata and Ohshima 2004; Ujiie et al. 1991; Ujiié and Ujiié 1999; Xu and Oda 1999). It was previously thought that during glacial periods, the $\mathrm{KC}$ did not enter the ECS and was deflected to the east side of the Ryukyu Island Arc (e.g., Ujiie et al. 1991; Ujiié and Ujiié 1999). At present, most studies agree that during the Last Glacial Maximum, the KC likely flowed into the southern part of the ECS. However, in the northern ECS, the KC probably shifted southeastward because of a stronger influence of coastal waters (e.g., Ijiri et al. 2005; Xie et al. 1995; Xu and Oda 1999). Recently, several geochemical studies have also tried to estimate changes in summer sea surface temperature (SST) and sea surface salinity (SSS) over the past $20 \mathrm{kyr}$ to monitor and understand the linkage between changes in EASM intensity and ocean response at millennial and centennial scales with the goal of quantifying and estimating the impact of the precipitation related to the EASM on the local paleoceanography of the ECS (e.g., Horikawa et al. 2015; Kubota et al. 2010, 2015a).

One of the concerns is that the paleoceanographic history of the ECS for periods older than $40 \mathrm{kyr}$ is poorly known because even long sediment cores $(\sim 33.65 \mathrm{~m}$ long in Ijiri et al. 2005) only cover the past $40 \mathrm{kyr}$ due to high sedimentation rates $(\sim 84.125 \mathrm{~cm} / \mathrm{kyr})$ in this area (e.g., Ijiri et al. 2005; Huh and Su 1999; Su and Huh 2002). Moreover, we still lack information about the changes in intermediate water hydrography of the ECS, such as the probable influence of the $\mathrm{KC}$ subsurface and the NPIW on the local paleoceanography. To document hydrographic changes of the subsurface and intermediate water is not easy in general because most paleoceanographic proxies relied on planktic and benthic foraminifers, which have calcareous skeletons and inhabit only shallow water $(<300 \mathrm{~m})$ and the seafloor, respectively (e.g., Gooday 2003; Fairbanks and Wiebe 1980; Kuroyanagi and Kawahata 2004). The microfossil group of radiolarians is the only abundant group bearing skeletons composed of amorphous silica $\left(\mathrm{SiO}_{2} \cdot \mathrm{nH}_{2} \mathrm{O}\right)$ and inhabiting deep to shallow water depths (e.g., Suzuki and Aita 2011; Suzuki and Not 2015). Numerous studies of radiolarians in the Northwest Pacific and its adjacent marginal seas have demonstrated the suitability of this microfossil group as a paleoceanographic proxy (e.g., Itaki et al. 2007, 2009; Kamikuri et al. 2007; Matsuzaki et al. 2014a, 2018; Okazaki et al. 2004). Recently, Integrated Ocean Drilling Program (IODP) Expedition 346, which aimed to reconstruct changes in EASM intensity since the Pliocene at high resolution, retrieved sediment cores at Site U1429 in the Danjo Basin of the northern ECS. These cores continuously cover the past $400 \mathrm{kyr}$ despite the high sedimentation rates in this area (Tada et al. 2015; Sagawa et al. 2018).

Therefore, in this study, we reconstructed the hydrographic changes of the intermediate and shallow water depths over the past $400 \mathrm{kyr}$ based on the ecological properties of selected radiolarian species at IODP Site U1429. Our objective was to clarify how the orbital parameters and their associated sea-level variations have influenced the local and regional hydrography during the last $400 \mathrm{kyr}$, with a particular focus on changes at intermediate water depths.

\section{Oceanographic setting of the study area}

The surface water of the ECS is influenced by warm, saline water from the KC and TWC (Tomczak and Godfrey 1994) (Fig. 1). The KC originates from the North Equatorial Current and transports warm-saline and 


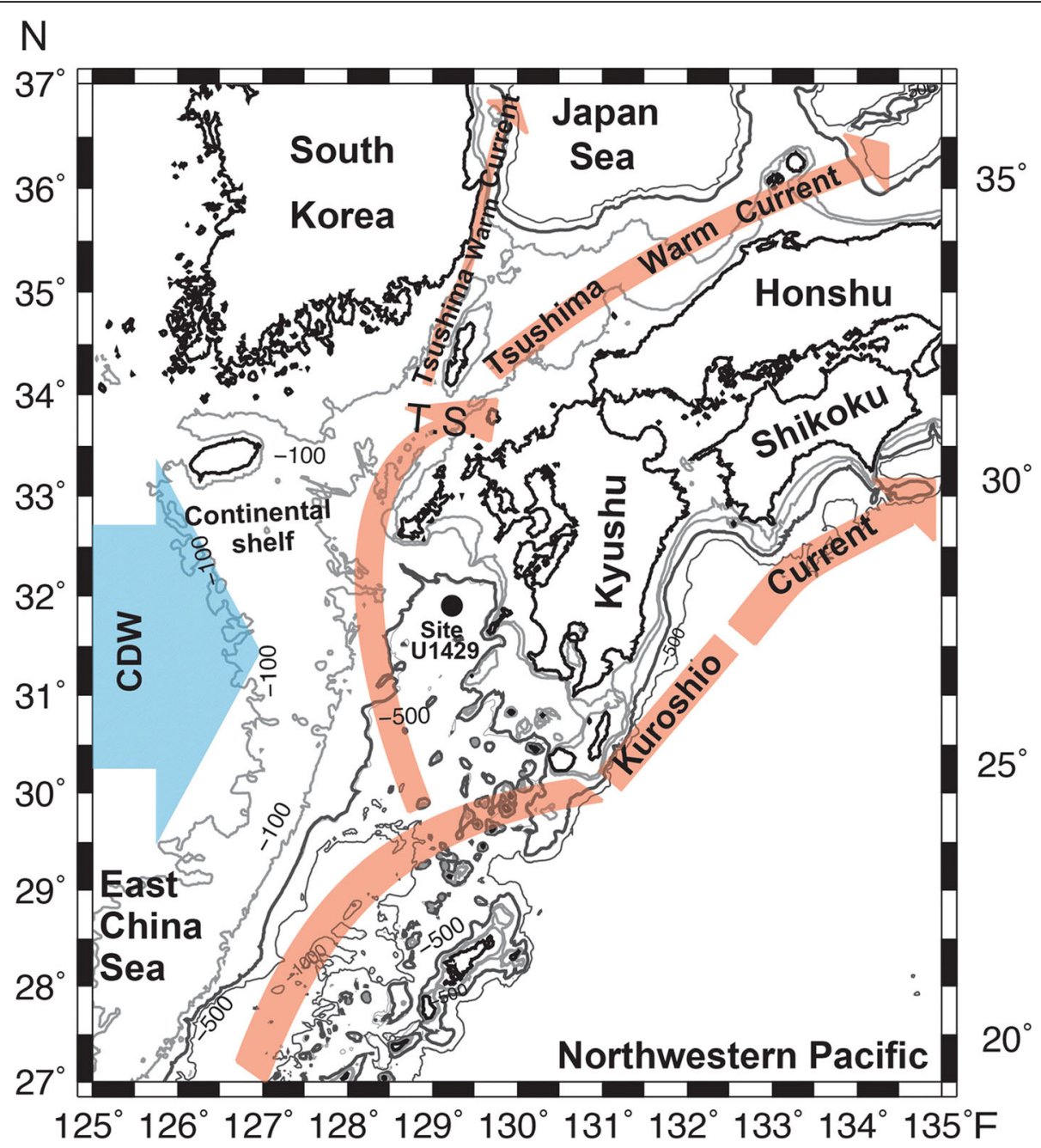

Fig. 1 Map from Matsuzaki et al. (2016) modified for this study to show the location of site U1429 and the key oceanographic features of the study area. CDW means Changjiang diluted water and IODP means Integrated Ocean Drilling Program

oligotrophic water northward. Its flow volume through the East Taiwan Strait varies seasonally due to the influence of the EASM, and the highest flow of $24 \mathrm{~Sv}(1 \mathrm{~Sv}=$ $10^{6} \mathrm{~m}^{3} / \mathrm{s}$ ) is recorded in summer, while lower flow occurs in autumn $(20 \mathrm{~Sv})$ (e.g., Lee et al. 2001; Kagimoto and Yamagata 1997; Qu and Lukas 2003). In addition, discharge of freshwater into the northwestern ECS from the Changjiang River causes the formation of a low-salinity seawater by mixing with the Taiwan Warm Current, the so-called Changjiang river diluted water (CDW) (Fig. 1) (e.g., Ichikawa and Beardsley 2002). The CDW flows southward along the Chinese coast during winter, whereas during summer, it flows as a southward coastal jet and has a northward spread (e.g., Beardsley et al. 1985). The thickness of the CDW is around $30 \mathrm{~m}$ in the middle shelf area, and it has a lower temperature and lower salinity than the KC surface water (e.g., Isobe and Matsuno 2008). During the summer, the SST and SSS of the shallow waters of the southern ECS water reach maxima of $28{ }^{\circ} \mathrm{C}$ and $34 \%$, respectively (Sun et al. 2005). In contrast, in the northern part of the ECS, between China and Kyushu Island, the SST and SSS are relatively low, $26{ }^{\circ} \mathrm{C}$ and $32 \%$, respectively. This difference is a consequence of the CDW into the northwestern ECS (Fig. 1; Ichikawa and Beardsley 2002). The total annual discharge of freshwater into the northwestern ECS from the Changjiang River reaches a maximum in summer (Beardsley et al. 1985). Therefore, the SSS and SST of the northern ECS are greatly reduced because of the CDW, which dominates the shallow continental shelf before being mixed with the warm, saline, oligotrophic water of the KC and TWC in the northeastern ECS (Fig. 1).

The ECS shelf area is one of the most productive marine areas of the world because of Changjiang River freshwater discharges $\left(9.24 \times 10^{11} \mathrm{~m}^{3}\right.$ year $\left.^{-1}\right)$ (Tian et al. 1993) and upwelling of the $\mathrm{KC}$ subsurface water from a water 
depth of 200-300 m near the slope of the ECS continental shelf (Wong et al. 1991; Chen and Wang 1999). These Kuroshio subsurface waters are known for being rich in nutrients such as nitrate (Chen and Wang 1999; Chen et al. 1999; Wong et al. 1991). Therefore, the nutrients brought up from the euphotic zone increases the local primary productivity (e.g., Chen 1996; Chen et al. 1999). The contribution of this nutrient upwelling is higher than that from the Changjiang and Yellow rivers (e.g., Chen and Wang 1999). Additionally, in the ECS, when the Kuroshio subsurface water upwells, although its influence is smaller, some studies have suggested that the NPIW probably mixes and upwells along the slope of the ECS continental shelf and also contributes to the formation of nutrient-rich shallow water (e.g., Chen 1996; Ito et al. 1994). The NPIW is formed in the Okhotsk Sea and is characterized by a salinity between 33.9 and $34.16 \%$ and an oxygen concentrations between 50 and $150 \mu \mathrm{mol} \mathrm{kg}$ (e.g., Kaneko et al. 2001; Bostock et al. 2010). This water mass subducted into and below the thermocline of the Kuroshio Extension before it enters subtropical gyres (e.g., Kaneko et al. 2001).

\section{Materials and methods}

\section{Core samples and age model}

In this study, we analyzed sediment core samples collected from Site U1429 during IODP Expedition 346. Site U1429 is located in the northernmost part of the ECS at a water depth of $732 \mathrm{~m}$ and coordinates $31^{\circ}$ 37.04' $\mathrm{N}$ and $128^{\circ} 59.85^{\prime} \mathrm{E}$ (Tada et al. 2015). This site is located in the southern part of the Danjo Basin, in the northern part of the Okinawa Trough (Tada et al. 2015). The cores are about $180 \mathrm{~m}$ long and characterized by calcareous-nannofossil-rich clay with diatoms and foraminifera (Tada et al. 2015). The retrieved sediments are heavily bioturbated and contain tephra layers of various thicknesses, ranging from centimeters to decimeters (e.g., Tada et al. 2015; Sagawa et al. 2018). This sedimentary succession was divided into two lithologic units (A and B) based on sediment composition (Tada et al. 2015). However, we did not analyze lithologic unit $B$ because of heavy drilling disturbance and poor recovery. Unit A spans the Holocene to Middle Pleistocene (0 to $400 \mathrm{kyr}$ ) and consists of olive-gray to light-greenish calcareous-rich clay with intercalation of tephra layers (Tada et al. 2015).

In this study, we used the core composite depth below seafloor (CCSF-D) scale of Irino et al. (2018). The depths in CCSF-D were then converted to ages (ka) following the age model proposed by Sagawa et al. (2018), which relies upon the oxygen isotope stratigraphy of benthic foraminifer tuned to the LR04 benthic stack (Lisiecki and Raymo 2005).

\section{Assemblage analysis}

In this study, we analyzed changes in the radiolarian assemblage for 124 samples at about 0.5 to $1.5 \mathrm{~m}$ intervals between 0 and $180 \mathrm{~m}$ CCSF-D. To monitor changes in the northern ECS hydrography, changes in radiolarian assemblages and absolute abundances were analyzed for a continuum of the past $400 \mathrm{kyr}$. Additionally, we estimated the variation in summer SST and intermediate water temperature at a depth of ca. $500 \mathrm{~m}$ by applying the method proposed by Matsuzaki and Itaki (2017). Two types of microscopic slides were mounted: faunal slides (F-slides) and quantitative slide (Q-slides). The first preparation steps were similar for both types of slide: the 124 samples were freeze-dried, treated with diluted hydrogen peroxide $\left(\mathrm{H}_{2} \mathrm{O}_{2}\right)(15 \%$, i.e., $50 \mathrm{ml}$ of $\mathrm{H}_{2} \mathrm{O}_{2}$ at a concentration of $30 \%$ diluted in $100 \mathrm{ml}$ of water) and hydrochloric acid (15\%) $(40 \mathrm{ml}$ of $\mathrm{HCl}$ at a concentration of $35-37 \%$ diluted in $100 \mathrm{~m}$ of water) to remove organic and calcareous matter. The undissolved residue in each sample was sieved through a $45-\mu \mathrm{m}$ screen following the method proposed in Tada et al. (2015). Once the undissolved residue was washed, we mounted slides following the procedures proposed by Itaki et al. (2009). Then, we examined polycystine radiolarians under an optical microscope at magnifications of $\times 100$ to $\times 400$ on both types of slide. All radiolarians were identified and counted until at least 400 individual tests were identified in each sample, or until the sample material was exhausted (see the Additional file 1). The identification followed the nomenclature of Itaki (2009), Matsuzaki et al. (2015a), and Zhang and Suzuki (2017). On average, we counted 435 specimens per slide.

We used changes in the entire radiolarian assemblage over time to estimate species diversity because they can be used to constrain changes in radiolarian productivity. We used the software PAST 3 of Hammer et al. (2001) to estimate the number of taxa (S), or species richness, which is a count of species recorded in each sample; we also determined the Shannon-Wiener index $\left(H^{\prime}\right)$, which describes species diversity by accounting for the relative proportion of each species within a sample as follows:

$$
H^{\prime}=-\sum P_{i} \ln P_{i},
$$

where $P_{i}$ is the proportion of each species $i$ in the sample (Shannon and Weaver 1949).

We also estimated species dominance $(D)$, which ranges from 0 (all taxa are equally present) to 1 (one taxon dominates the community completely), as follows:

$$
D=\sum\left(n_{i} / n\right)^{2}
$$

where $n_{i}$ is number of individuals of taxon $i$ and $n$ is the total number of samples (e.g., Harper 1999). The dominance is related to the Simpson index $(D=1-$ Simpson 
index); however, in this study, the use of $D$ was more useful for explaining our dataset.

From the full assemblage, where 144 species were identified in 124 samples (see the Additional file 1), we selected 45 species with well-known geographic and vertical distributions for reconstructing the paleo-summer SST and intermediate water temperature following the nomenclature of Matsuzaki and Itaki (2017). Then, to reconstruct the regional paleoceanography over the past $400 \mathrm{kyr}$, we selected ten species whose ecology is well understood for the ECS based on the findings of Matsuzaki et al. (2016) (Figs. 2 and 3).

\section{Sea surface and intermediate water temperature estimation}

We estimated the SST and intermediate water temperature at a water depth of ca. $500 \mathrm{~m}$ by applying the method proposed by Matsuzaki and Itaki (2017), who used the transfer function of Imbrie and Kipp (1971) on a dataset composed of 87 surface sediments collected in the Northwest Pacific with a particular focus on the seas surrounding Japan, including the northern ECS, where more than 20 surface sediment samples were analyzed [see Matsuzaki and Itaki 2017 for details]. Briefly, modern summer SST and intermediate water temperature at a water depth of ca. $500 \mathrm{~m}$ were attributed to each of the analyzed locations using the World Ocean Atlas 2013 (Locarnini et al. 2013) and interpolated (with a $1 \times 1^{\circ}$ grid) onto the geographic position of each surface sediment station, as detailed in Matsuzaki and Itaki (2017). Following the method of Matsuzaki and Itaki (2017), we selected 28 species living in shallow water (upper $200 \mathrm{~m}$ ) for SST estimation and 17 species living at intermediate water depths for the estimation of intermediate water temperatures (Additional file 2: Table S1 and Additional file 3: Table S2).

For the SST estimates, all the selected species shown in Additional file 2: Table S1 overlap with a water depth of $0 \mathrm{~m}$ (e.g., Matsuzaki et al. 2016; Matsuzaki and Itaki 2017; Okazaki et al. 2004). Thus, we assumed that the reconstructed SST based on these selected shallow-water species reflect a water depth of $0 \mathrm{~m}$. However, in Matsuzaki and Itaki (2017), the approach adopted by the University of Bremen was used (i.e., http://www.geo.uni-bremen.de/geomod/ staff/csn/woa-sample.html), which integrates the temperature data for the upper $10 \mathrm{~m}$ provided by the World Ocean Atlas. Therefore, the reconstructed SST corresponds to an average of the upper $10 \mathrm{~m}$ of the water column. In addition, as shown in Matsuzaki and Itaki (2017), we assumed that the reconstructed SST corresponds to the summer SST because the radiolarian flux is generally low during winter in the Northwest Pacific (e.g., Itaki et al. 2008; Okazaki et al. 2005; 2008). For the intermediate water temperature estimates, a similar assumption was adopted. The selected 17 intermediate water species overlapped with water depths of $500 \mathrm{~m}$, and thus we assumed that intermediate water temperatures reconstructed using these selected species corresponded to those of water ca. $500 \mathrm{~m}$ deep. Then, intermediate water temperatures at ca. $500 \mathrm{~m}$ provided by the World Ocean Atlas were interpolated (i.e., Matsuzaki and Itaki 2017). The relative abundance of the selected species was normalized using the procedures of Matsuzaki and Itaki (2017). The selected species and their normalized abundances are shown in Additional file 2: Table S1 and Additional file 3: Table S2. The SST and intermediate water temperature were then quantified using the PAST software (Hammer et al. 2001), which implements the CABFAC and REGRESS routines of the original method of Imbrie and Kipp (1971) for Q-mode factor analysis (i.e., Matsuzaki and Itaki 2017).

\section{Results}

\section{Radiolarian absolute abundances}

We estimated $1.25 \times 10^{4}$ skel. $\mathrm{g}^{-1}$ to be the median absolute abundance of radiolarians at Site U1429 (Fig. 4). In this study, we considered values higher than the median to represent high radiolarian abundance. The interval between 0 and $240 \mathrm{ka}$, which corresponds to MISs 1-7, was characterized by high radiolarian absolute abundances. For this period, most of the estimated absolute abundances were higher than the median and exceeded $2.5 \times 10^{4}$ skel. $g^{-1}$ during interglacial periods (MISs 1,5 , and 7; Fig. 4). During glacial periods (MISs 2, 4, and 6), radiolarian absolute abundance was lower than the median in only a few intervals: at about 20 ka during MIS 2; at about $70 \mathrm{ka}$ during MIS 4; and at about 130 and 190 ka during MIS 6 (Fig. 4). Therefore, radiolarian abundance was generally high between 0 and $240 \mathrm{ka}$, with the highest absolute abundances attained during warm interglacial periods. In contrast, the time interval between 240 and $400 \mathrm{ka}$ was characterized by lower radiolarian absolute abundances (Fig. 4). Most of the values in this interval are lower than the median.

\section{Radiolarian diversity}

We estimated radiolarian diversity by analyzing the full radiolarian assemblage (the list of taxa is provided in the Additional file 1). We assumed that the number of taxa $(\mathrm{S})$ of radiolarian species and species groups can be used as a diversity index. The median number of species per sample was 57 (Fig. 4). The species diversity was higher during interglacial periods, with a maximum during MIS 5, when the number of radiolarian species exceeded 90 (Fig. 4). Additionally, a drastic increase in the number of radiolarian species was recorded at the MIS 5/6 boundary (ca. $130 \mathrm{ka}$ ). Before the MIS 5/6 boundary, the number of radiolarian species (and thus 


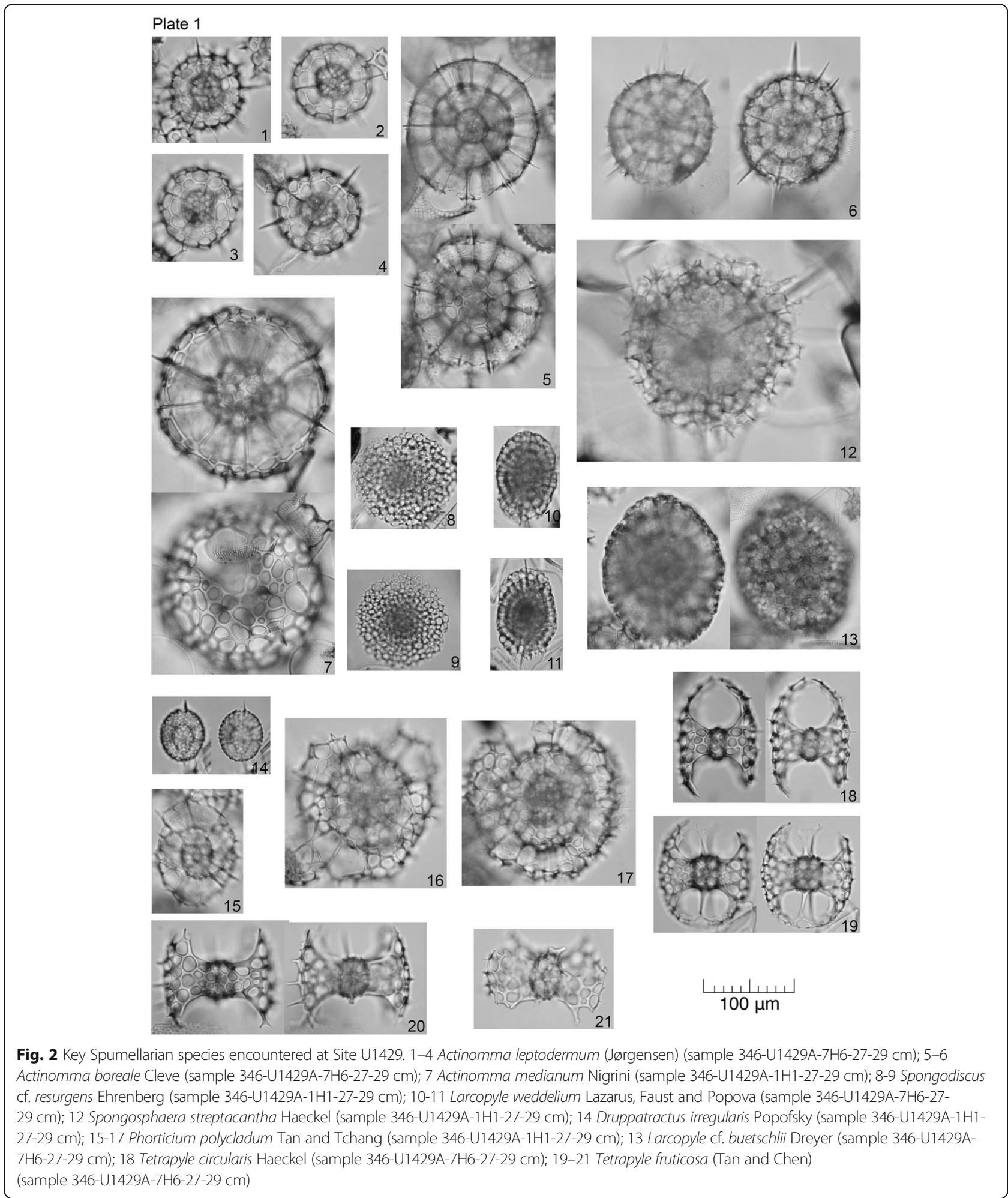

the diversity index) was lower than or close to the median value of 57 and never exceeded 70 (Fig. 4). Thus, radiolarian diversity was higher between 0 and $130 \mathrm{ka}$ than between 130 and $400 \mathrm{ka}$.
We also calculated the species dominance index $(D)$ to assess the evenness of the radiolarian assemblages (Fig. 4). The median value of $D$ was 0.05 during the past $400 \mathrm{kyr}$ at Site U1429 (Fig. 4). High species dominance 

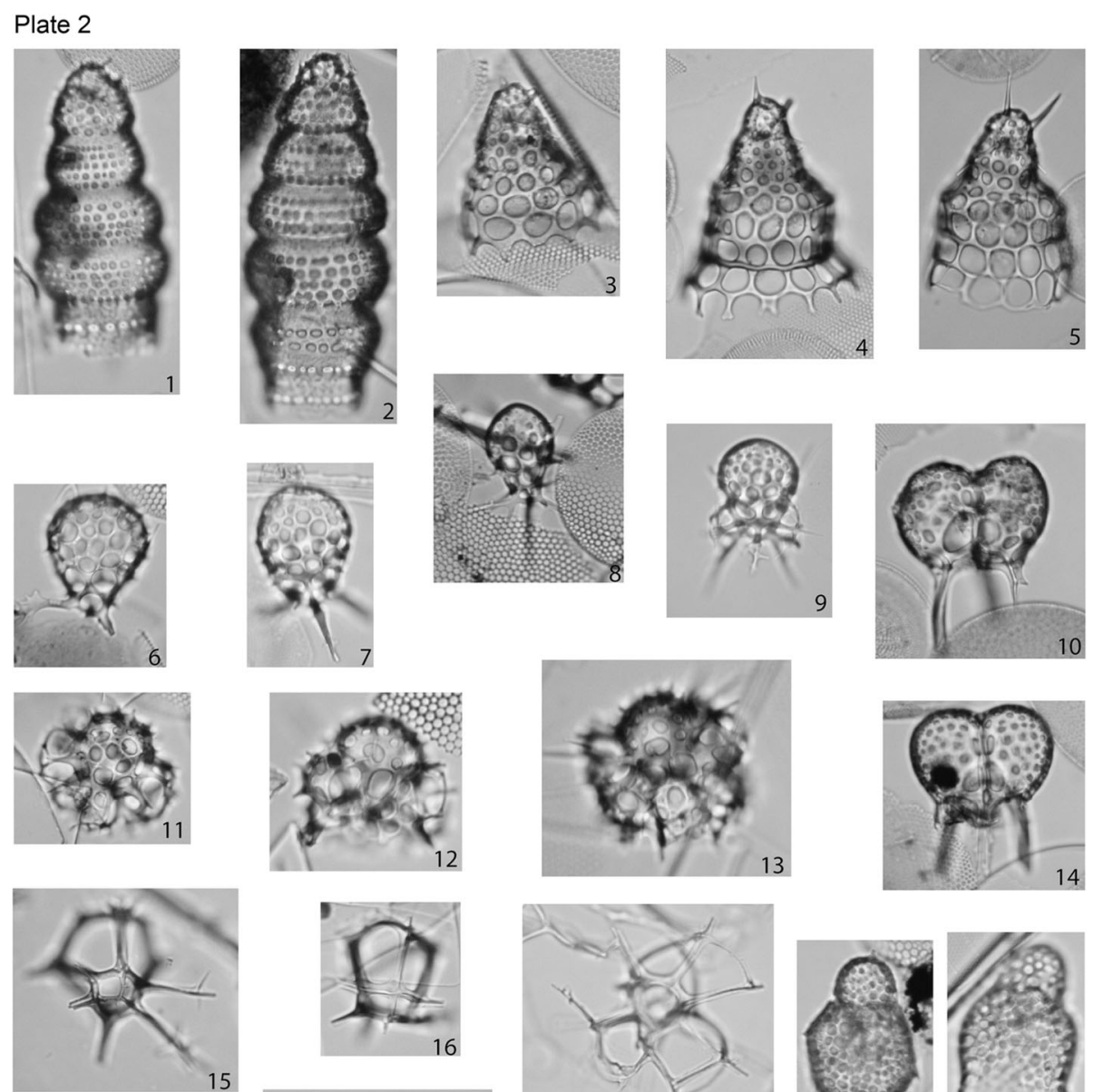

15
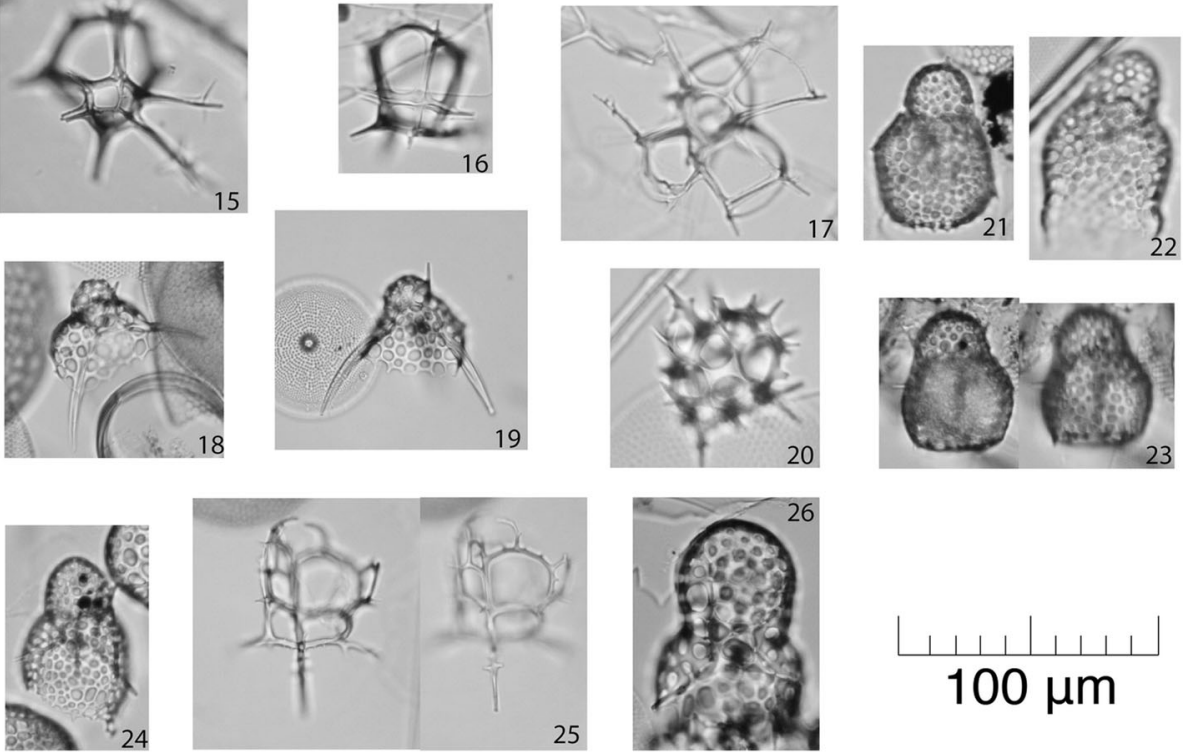

Fig. 3 Key Nassellarian species encountered at Site U1429. 1-2 Botryostrobus auritus (Ehrenberg) (sample 346-U1429A-7H6-27-29 cm); 3-5 Cycladophora davisiana Ehrenberg (sample 346-U1429C-10H4-27-29 cm); 6-9 Arachnocorallium calvata Petrushevskaya group (sample 346-U1429A7H6-27-29 cm); 10, 14 Phormospyris spp. (10. sample 346-U1429C-10H4-27-29 cm, 11 sample 346-U1429A-7H6-27-29 cm); 11-13 Arachnocorys castanoides Tan and Tchang (sample 346-U1429A-1H1-27-29 cm); 15-17 Pseudocubus obeliscus Haeckel (sample 346-U1429A-7H6-27-29 cm); 21-24 Lithomelissa setosa Jørgensen (sample 346-U1429A-7H6-27-29 cm); 18-19 Pseudodictyophimus gracilipes (Bailey) (sample 346-U1429C-10H4-27-29 cm); 20 Plectacantha oikiskos (Jørgensen) (Sample 346-U1429A-7H6-27-29 cm); 26 Dimelissa thoracites (Haeckel) (sample 346-U1429A-1H1-27-29 cm); 25 Phormacantha hystrix Jørgensen

is recorded at the MIS 6/7 boundary, with several successive values higher than the median (Fig. 4). However, the highest values of $D$ were recorded between MIS 2 and late MIS 5, with the maximum value being approximately 0.20 (Fig. 4). This result suggests that during MISs 2-4, the radiolarian assemblage was likely dominated by a single species, and thus ecological conditions enabling this dominance prevailed. 


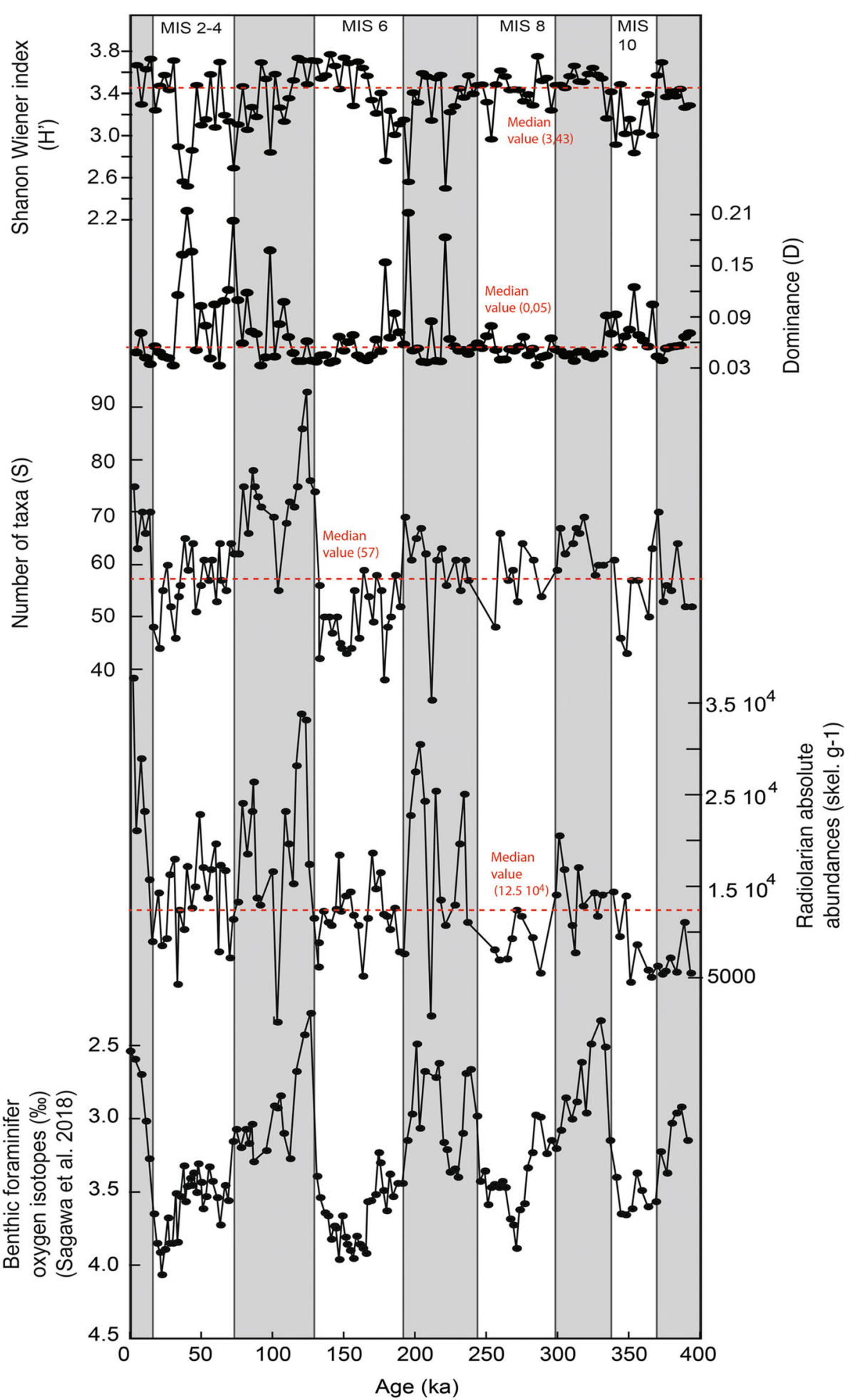

Fig. 4 Radiolarian absolute abundance. The number of taxa (S), dominance index (D), and Shannon-Wiener diversity index ( $\left.\mathrm{H}^{\prime}\right)$ are shown over time and compared to the benthic foraminifera isotope curve of Sagawa et al. (2018). Red lines indicate median values

The last species diversity index that we calculated was the Shannon-Wiener index $\left(\mathrm{H}^{\prime}\right)$. The median value of this index is 3.43 (Fig. 4). In general, between mid-MIS 6 and MIS 11, $\mathrm{H}^{\prime}$ was close to the median value; however, between mid-MIS 6 and MIS 1, except for MIS 2, the index value was slightly higher, close to 3.8 . This result 
suggests higher species diversity for the mid-MIS 6 to MIS 1 time interval, except for MIS 2. During intervals of high species dominance (MISs 2-4 and at the MIS 6/7 boundary), $\mathrm{H}^{\prime}$ was at a minimum, with values close to 2.6 (Fig. 4).

In general, the values of the diversity index suggest that radiolarian species diversity increased after $130 \mathrm{ka}$ (MISs 1 and 5).

\section{Relative abundances of selected species}

We selected ten species or species groups that are useful for reconstructing the paleo-hydrography of the northern ECS over the past $400 \mathrm{kyr}$ from the full radiolarian assemblage (Fig. 5). Species selection was conducted with reference to Matsuzaki et al. (2016): in that study, radiolarians collected from plankton tows were analyzed to clarify the regional spatial and vertical radiolarian distributions (see Matsuzaki et al. (2016) for details). The raw data of the present study are available in the Additional file 1.

In the northern ECS (Site U1429), the occurrence of the Tetrapyle circularis/fruticosa group (Fig. 5b) sensu Zhang and Suzuki (2017) was high during each interglacial period (i.e., MISs 1, 5, 7, 9, and 11; Fig. $5)$. The highest abundance of the $T$. circularis/fruticosa group (>22\%) was recorded during MIS 9 (300$337 \mathrm{ka}$ ). Recently, it has been proven that all species belonging to the Tetrapyle genus have algal symbionts and inhabit warm shallow water (Zhang et al. 2018). In addition, this species group has been found in areas influenced by warm-water currents (e.g., the KC and its related branches), such as the northern ECS, Japan Sea, and Japan's Pacific coast (e.g., Lombari and Boden 1985; Itaki et al. 2004, 2007, 2010; Motoyama and Nishimura 2005; Kamikuri et al. 2008; Itaki 2009, 2016; Boltovskoy et al. 2010; Matsuzaki et al. 2014a, 2015a, 2015b, 2016; Botovskoy and Correa 2016; Matsuzaki and Itaki 2017). Therefore, the high abundance of $T$. circularis/fruticosa during interglacial periods implies an influence of the KC at Site U1429 (Fig. 5). Additionally, the maximum abundance of the $T$. circularis/fruticosa group and its fluctuation pattern changed between MISs 6 and 7. For MISs 1 and 5, an increase in $T$. circularis/fruticosa abundance occurred after a sea-level rise, whereas for MISs 7 and 9 , increases in $T$. circularis/fruticosa abundance were almost synchronous with a sea-level rise (Fig. 5).

Didymocyrtis tetrathalamus (Haeckel) (Fig. $5 \mathrm{~g}$ ) is also known to inhabit shallow warm water (e.g., Lombari and Boden 1985; Boltovskoy et al. 2010; Botovskoy and Correa 2016; Matsuzaki and Itaki 2017). However, at the study site, $D$. tetrathalamus exhibited no significant variations in abundance in response to glacial-interglacial cycles, and its relative abundance rarely exceeded $2 \%$ of the assemblage (Fig. 5).

The species Lithomelissa setosa Jørgensen (Fig. 5c) was almost absent from Site U1429 during interglacial periods; in contrast, it dominated the radiolarian assemblages during glacial periods, with relative abundances greater than $30 \%$ of the total assemblage, except during MIS 8 (Fig. 5). L. setosa is a transitional-subarctic species, and it is abundant along the coasts of the Sea of Okhotsk and northeastern Japan (e.g., Itaki et al. 2008; Matsuzaki and Itaki 2017). In the northern Atlantic, L. setosa is dominant in fjord areas (Bjørklund et al. 1974). Additionally, Itaki et al. (2008) suggested that this species is probably characteristic of nutrient-rich coastal areas. Therefore, our data suggest that during MISs 2-4, 6, and 10, Site U1429 was influenced by relatively cold, nutrient-rich coastal water.

At present, Pseudocubus obeliscus Haeckel (Fig. 5d) is an abundant species in the northern ECS (Matsuzaki et al. 2016). In our data, this species exhibited higher relative abundances, with values close to $10 \%$ of the assemblage, when the sea level was rising or falling, such as at MIS boundaries (Fig. 5).

The species Arachnocorallium calvata Petrushevskaya (Fig. 5e) is associated with the shallow water of the ECS continental shelf and is probably characteristic of ECS continental shelf water (Matsuzaki et al. 2016). In our data, the relative abundances of $A$. calvata were slightly higher for the period between 0 and $170 \mathrm{ka}$, for which a relative abundance higher than $6 \%$ was recorded (Fig. 5).

The species Actinomma medianum Nigrini (Fig. 5f) exhibited low abundance throughout the core, except during MIS 10 (337-375 ka), in which the relative abundance of this species exceeded $5 \%$ of the total assemblage (Fig. 5). At present, this species is associated with transitional waters of the Northwest Pacific, where the $\mathrm{KC}$ and Oyashio Current mix (Matsuzaki and Itaki 2017). This distribution suggests that MIS 10 probably was warmer than other glacial periods. In addition, Lithomelissa setosa was less abundant during MIS 10 (Fig. 5), consistent with this interval being warmer.

The species group Actinomma boreale/leptodermum sensu Itaki et al. (2004) showed higher relative abundances between 100 and $290 \mathrm{ka}$, which corresponds to MISs 5-9 (Fig. 5h). Two high-abundance peaks (> 20\% of the total assemblage) were recorded during MIS 6 at ca. 140 and $180 \mathrm{ka}$ (Fig. 5). Additionally, the relative abundance of this species was nearly $10 \%$ of the total assemblage almost continuously between 190 and 290 ka (Fig. 5). This species is a subarctic species (e.g., Kling 1979; Okazaki et al. 2004; Kamikuri et al. 2008), and in the modern ECS, it dominates the assemblage at 


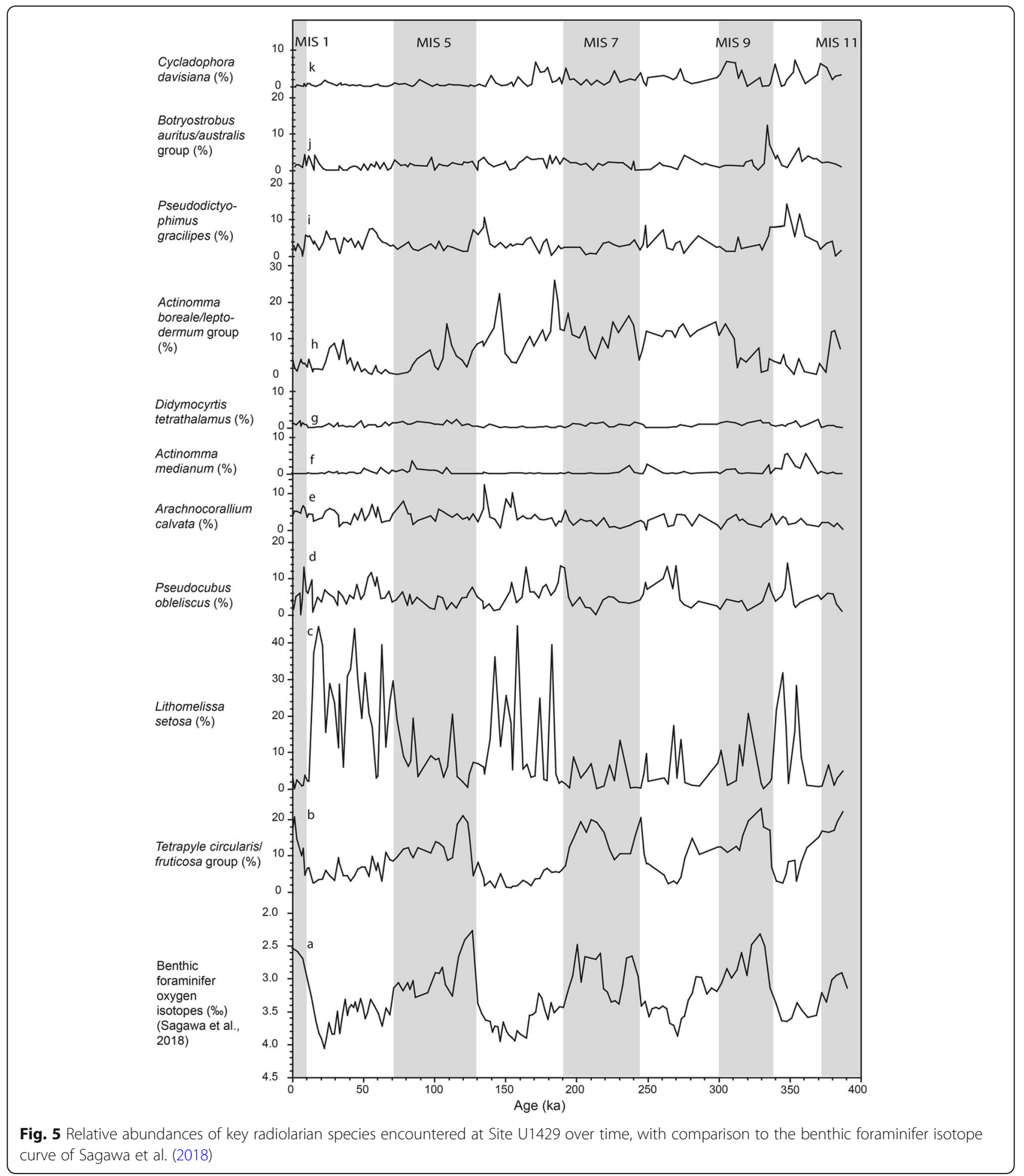

intermediate water depths (Matsuzaki et al. 2016). However, Pseudodictyophimus gracilipes (Bailey) had its highest abundance during MIS 10 (337-375 ka; Fig. 5i). Pseudodictyophimus gracilipes is also a subarctic species that lives at intermediate water depths in the ECS (Matsuzaki et al. 2016), although it inhabits shallow to subsurface water depths at higher latitudes (e.g., Kling 1979; Okazaki et al. 2004). High abundances of these species may suggest a greater influence of subarctic water at intermediate water depths in the ECS from 100 to $290 \mathrm{ka}$ and from 337 to $375 \mathrm{ka}$. 
The Botryostrobus auritus/australis (Ehrenberg) group showed high abundance during the earliest stages of MIS 9 (300-337 ka), when its relative abundance exceeded $10 \%$ of the total assemblage (Fig. 5j). The ecology of this species at that time is largely unknown, but Matsuzaki and Itaki (2017) found that this species is probably related to the intermediate water of southern Japan.

The abundance of Cycladophora davisiana Ehrenberg (Fig. 5k) was more than $5 \%$ of the total assemblage between ca. 160 and $400 \mathrm{ka}$. The ecology of this species is well understood: its presence implies cold, oxygen-rich intermediate water (e.g., Boltovskoy and Riedel 1987; Kling and Boltovskoy 1995; Okazaki et al. 2003; Itaki and Ikehara 2004; Abelmann and Nimmergut 2005; Itaki et al. 2009; Matsuzaki et al. 2014b; Matsuzaki and Itaki 2017). Therefore, our data indicate that, the intermediate water depth of the
ECS was likely cold and well ventilated at 160-400 ka.

\section{Summer SST and intermediate water temperature variations over the past $\mathbf{4 0 0} \mathbf{k y r}$}

By applying the dataset and method proposed by Matsuzaki and Itaki (2017), we estimated the paleo-summer SST and intermediate water temperature at ca. $500 \mathrm{~m}$ based on the selected radiolarian species using the transfer function of Imbrie and Kipp (1971) with an error margin of $0.9^{\circ} \mathrm{C}$ for paleo-summer SST and $1.2{ }^{\circ} \mathrm{C}$ for intermediate water temperature (Fig. 6 and Additional file 4: Table S3; see Matsuzaki and Itaki 2017 for details).

Our reconstruction shows that the paleo-summer SST at Site U1429 fluctuated between 18.1 and $28.3{ }^{\circ} \mathrm{C}$, with an error margin of $0.9{ }^{\circ} \mathrm{C}$ (Fig. 6). During each

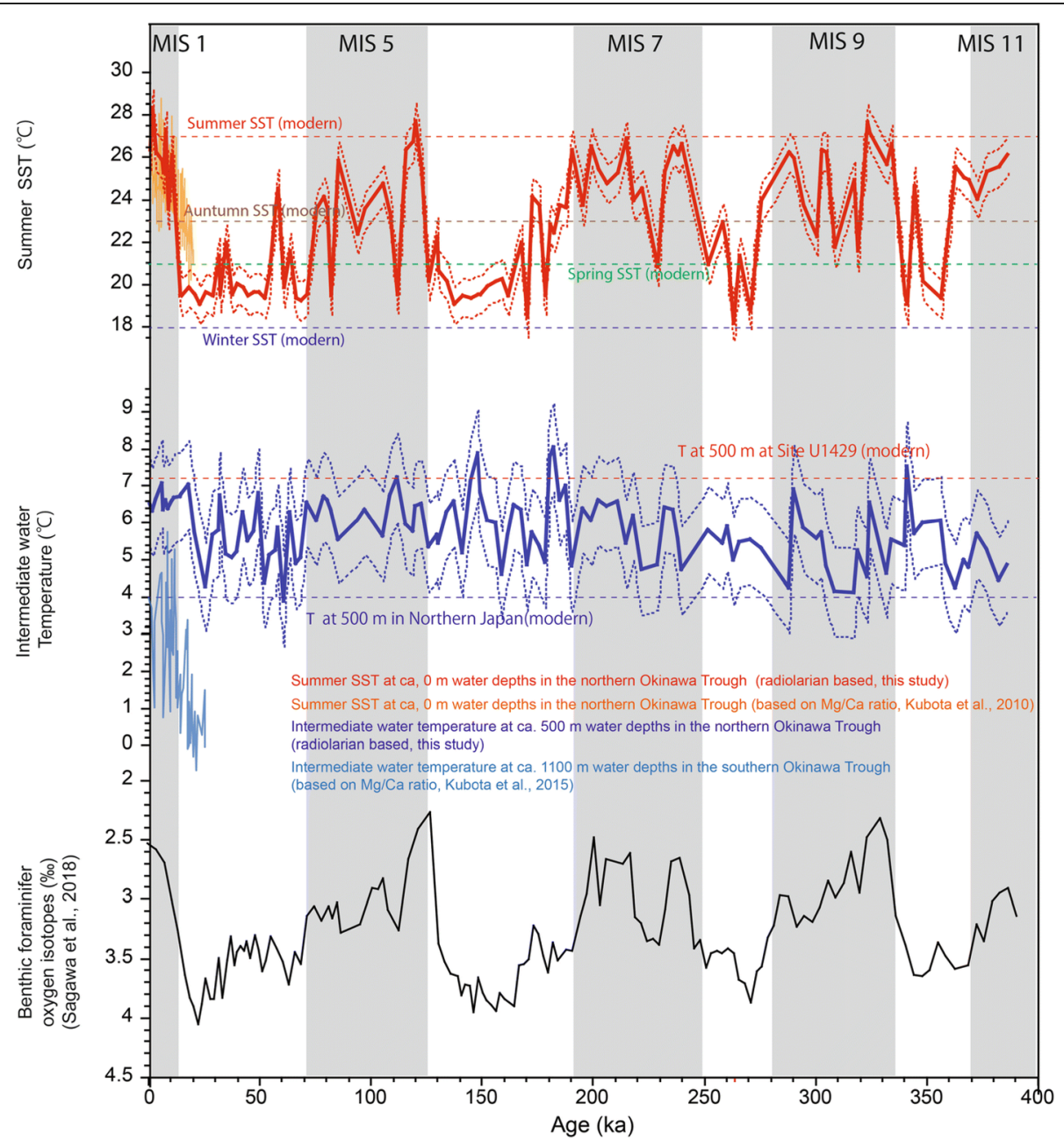

Fig. 6 Radiolarian-based estimates for intermediate water temperature and SST over time and compared to the benthic foraminifera isotope curve of Sagawa et al. (2018). Dashed curves indicate modern median temperatures. Also shown are the summer SST estimated using the Mg/Ca ratio of planktic foraminifera (Kubota et al. 2010) in the northern Okinawa Trough and bottom water temperature estimated using the Mg/Ca ratio of benthic foraminifera in the southern Okinawa Trough (Kubota et al. 2015b) 
interglacial period, the summer SST exceeded $26{ }^{\circ} \mathrm{C}$, with a maximum of $28.3^{\circ} \mathrm{C}$ at $1.5 \mathrm{ka}$ (MIS 1), whereas during glacial periods, the summer SST was between 18 and $22{ }^{\circ} \mathrm{C}$, with a minimum of $18.1{ }^{\circ} \mathrm{C}$ at $263 \mathrm{ka}$ (MIS 8; Fig. 6). During interglacial periods, our reconstructed summer SST values are close to the modern summer SST $\left(27^{\circ} \mathrm{C}\right)$ at Site U1429; the values for glacial periods are between those of modern winter and spring SSTs $\left(17-21{ }^{\circ} \mathrm{C}\right.$; Locarnini et al. 2013; Fig. 6).

The reconstructed intermediate water temperature at ca. $500 \mathrm{~m}$ fluctuated between 3.9 and $8.0{ }^{\circ} \mathrm{C}$, with an error margin of $1.2{ }^{\circ} \mathrm{C}$ (Fig. 6). These temperatures correspond to the modern intermediate water temperature at ca. $500 \mathrm{~m}$ water depth at Site U1429 (ca. $7{ }^{\circ} \mathrm{C}$ ) and the temperature at ca. $500 \mathrm{~m}$ off northern Japan (ca. $4{ }^{\circ} \mathrm{C}$; Locarnini et al. 2013). The maximum value of $8.0 \pm 1.2^{\circ} \mathrm{C}$ was recorded at $180 \mathrm{ka}$ (during MIS 6); the minimum of $3.9 \pm 1.2{ }^{\circ} \mathrm{C}$ was recorded at ca. $60 \mathrm{ka}$ (MIS 4; Fig. 6). Although the glacial to interglacial variation is within the error range of the method, the reconstructed intermediate water temperature at ca. $500 \mathrm{~m}$ seems to indicate warmer temperatures during interglacial periods and colder temperatures during glacial periods between 0 and $130 \mathrm{ka}$ (MISs 1-5; Fig. 6). However, for older time intervals, there appears to be no correlation with glacial-interglacial cycles.

\section{Discussion}

\section{Comparison of radiolarian-based summer SST and intermediate water temperatures}

We compared our SST data with the results of Kubota et al. (2010), who estimated summer SSTs on the basis of variations in the $\mathrm{Mg} / \mathrm{Ca}$ ratio of the planktic foraminifer Globigerinoides ruber (D'Orbigny). The radiolarian-based summer SST and $\mathrm{Mg} / \mathrm{Ca}$ variation-based summer SST are similar for interglacial periods, confirming the suitability of our method. However, there are some discrepancies between the two sets of results for glacial periods (Fig. 6): radiolarian-based summer SSTs are ca. $2{ }^{\circ} \mathrm{C}$ colder than those inferred from foraminifera. Although there is no clear explanation for this pattern at this time, we hypothesize that for glacial periods, our summer SST values do not reflect the temperature near the water surface but rather the temperature at ca. $100 \mathrm{~m}$. During glacial periods, the dominant radiolarian species was Lithomelissa setosa (Additional file 2: Table S1), which inhabits the subsurface (e.g., Bjørklund et al. 1974; Itaki 2004; Matsuzaki et al. 2016). Therefore, our glacial-period SST values may reflect the subsurface sea temperatures, whereas during interglacial periods, because of the high abundances of $\mathrm{KC}$ species that prefer the upper $25 \mathrm{~m}$ of the water column in the northern ECS (Matsuzaki et al. 2016), it is likely that we obtained information on the part of the environment similar to the habitat of G. ruber (0-
50 m, Kuroyanagi and Kawahata 2004). However, because the ECS is strongly affected by local and regional influences, such as the EASM, which causes freshwater and sediment discharges into the ECS, it is also possible that the $\mathrm{Mg} / \mathrm{Ca}$ ratio of foraminifera was influenced by such factors. To test this hypothesis, the radiolarian-based SST should be compared again with the SST estimated from $\mathrm{Mg} / \mathrm{Ca}$ ratios in foraminifera and, if possible, the alkenone-based SST in an area less subject to such regional influences, such as the open ocean.

We also compared our reconstructed intermediate temperature data with those of Kubota et al. (2015b), who estimated the seawater temperatures at $1100 \mathrm{~m}$ depth in the southern Okinawa Trough from variations in benthic foraminifera $\mathrm{Mg} / \mathrm{Ca}$ ratios. Our intermediate water temperature curve fluctuates in a manner similar to that of the temperature estimated using benthic foraminifera $\mathrm{Mg} / \mathrm{Ca}$ over the last $15 \mathrm{kyr}$ (Fig. 6). Although we note a discrepancy of ca. $3{ }^{\circ} \mathrm{C}$, it can easily be explained by the effect of water depth. Indeed, our temperature estimates correspond to a water depth of ca. 500 m, whereas those of Kubota et al. (2015b) are for water depths of ca. $1100 \mathrm{~m}$, and it is reasonable to record warmer temperatures at shallower depths.

\section{Evolution of local shallow water over the last $\mathbf{4 0 0} \mathbf{~ k y r}$}

The hydrography of the ECS shallow water is sensitive to glacio-eustatic sea-level changes caused by glacialinterglacial cycles (Figs. 5, 7, and 8). Based on the paleoceanographic changes inferred from our radiolarian data, as described in the "Results" section, an overview of ECS shallow-water hydrography during each of the three sea-level regimes that have prevailed during the past 400 kyr is provided in Fig. 8.

\section{Evolution of local shallow water during interglacial periods}

The fluctuations of the radiolarian-based summer SST curve are generally synchronous with those of the oxygen isotope curve of benthic foraminifera at Site U1429 (Sagawa et al. 2018). The summer SST values were close to the modern summer SST during interglacial periods (ca. $27^{\circ} \mathrm{C}$ ) (Fig. 6). This increase in SST was caused by the presence of the $\mathrm{KC}$ at Site U1429. Indeed, the radiolarians Tetrapyle circularis/fruticosa and Didymocyrtis tetrathalamus, which are markers of $\mathrm{KC}$ water in the Northwest Pacific (e.g., Lombari and Boden 1985; Boltovskoy et al. 2010; Hernández-Almeida et al. 2017; Matsuzaki and Itaki 2017), showed relative abundances higher than 15\% during MISs 1, 5, 7, 9, and 11 (Fig. 7). This finding suggests that $\mathrm{KC}$ water influenced the shallow water of the northern ECS during each interglacial period of the past $400 \mathrm{kyr}$ (Fig. 7). This result is in agreement with previous studies suggesting that the $\mathrm{KC}$ influenced the northern ECS during interglacial periods 


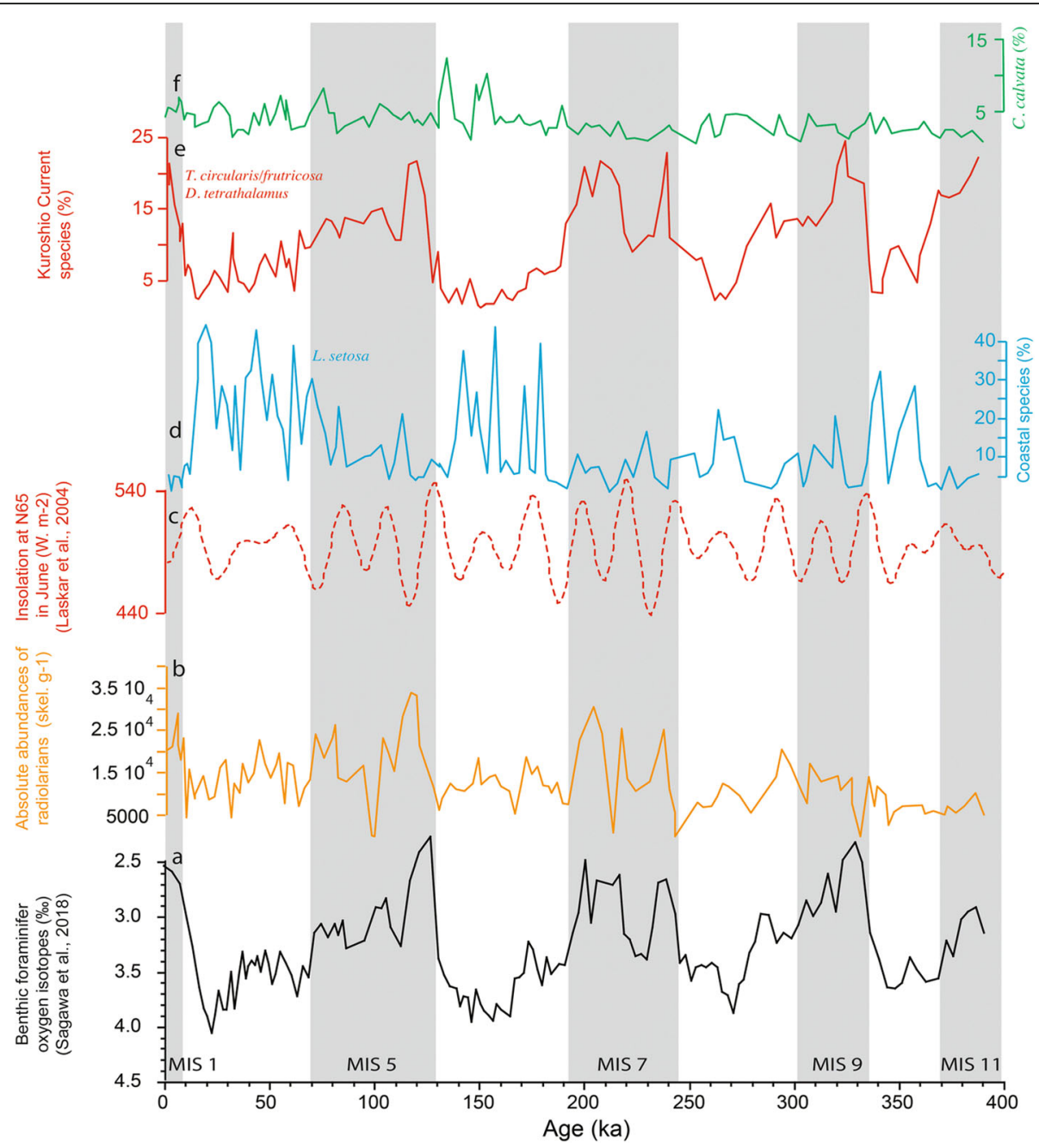

Fig. 7 Temporal fluctuation of various radiolarian abundances: a benthic foraminifera isotope curve of Sagawa et al. (2018), b radiolarian absolute abundance, $\mathbf{c}$ insolation at $65^{\circ} \mathrm{N}$ (Paillard et al. 1996), d coastal water species (\%), e KC-related species (\%), and $\mathbf{f}$ continental shelf species (\%)

(Xie et al. 1995; Xu and Oda 1999; Ijiri et al. 2005; Shi et al. 2014). Our study also demonstrates that the path of the $\mathrm{KC}$ was probably similar to the modern path during every interglacial period of the past $400 \mathrm{kyr}$.

However, for MIS 1 and MIS 5, the SST and the relative abundances of $\mathrm{KC}$ species increased after the benthic foraminiferal $\delta^{18} \mathrm{O}$ values reached a low point, which indicates a sea-level maximum (Figs. 5 and 7). Furthermore, the abundance of Arachnocorallium calvata increased at those times (Fig. 7). This species is known to inhabit the ECS shelf water (Matsuzaki et al. 2016); thus, our data imply that when the sea-level rose and reached a maximum, shelf water expanded eastwards and influenced our study site. Therefore, the $\mathrm{KC}$ only influenced our site and the northern ECS after the rise in sea level. These MIS transitions correspond to maxima of summer insolation at $65^{\circ} \mathrm{N}$. In the ECS, and Asia in general, maxima of summer insolation at $65^{\circ} \mathrm{N}$ are associated with maxima of EASM intensity, which causes an increase in precipitation. Thus, during these maxima, discharges of freshwater into the ECS are higher (e.g., Wang et al. 2001, 2008). Therefore, in the ECS, it is probable that intensification of the EASM and the related southeastwards expansion of ECS shelf water weakened the KC inflow that passes across the northern ECS at the MIS $1 / 2$ and MIS 5/6 transitions (Fig. 8).

\section{Evolution of local shallow water during glacial periods}

During the last glacial period (MIS 2), the ECS continental shelf was exposed, which triggered eastward migration of the coastlines and river mouths of the main Chinese rivers (Xie et al. 1995; Xu and Oda 1999; Kawahata and Ohshima 2004; Ijiri et al. 2005). However, the paleoceanography of older glacial periods has remained unknown because of the lack, until now, of sediment cores covering time intervals prior to $40 \mathrm{ka}$. Based on 


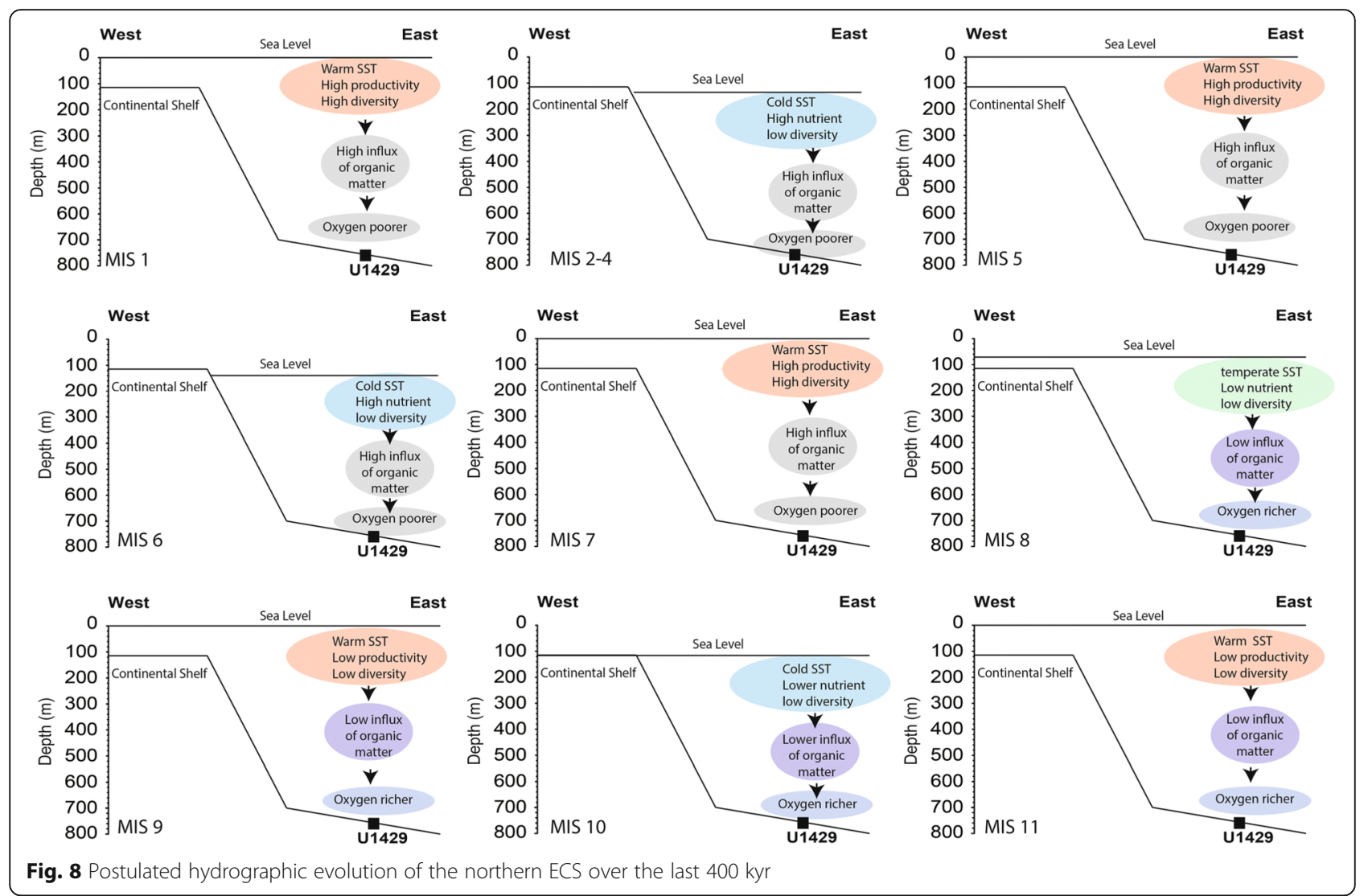

our data, the paleoceanographic conditions during MISs $2-4,6$, and 10 were likely very similar, although MIS 10 was probably warmer because Actinomma medianum, a transitional species of the North Pacific, exhibited relative abundances of about 5\% (Figs. 5 and 7). Thus, a similar sea-level drop probably occurred during MISs 24, 6, and 10 (Fig. 8). This scenario is consistent with a recent study that attempted to separate the effects of temperature and global ice volume on deep-ocean foraminiferal $\delta^{18} \mathrm{O}$ values (Elderfield et al. 2012). The radiolarian Lithomelissa setosa, a coastal-water species, dominated the assemblage with relative abundances exceeding $40 \%$ during these glacial periods (Fig. 7). In the modern era, $L$. setosa dominates the coastal environment of northern Japan and is absent offshore (Kamikuri et al. 2008; Matsuzaki and Itaki 2017). Additionally, this species is probably associated with nutrient-rich coastal water created by suspension of lithogenic matter (Itaki et al. 2008). Therefore, our data suggest that during MISs 2-4, 6, and 10, nutrient-rich coastal water prevailed because of probable higher input of terrigenous matter and consequent eastward migration of the coastline.

For MISs 2-4 and 6, high variability in Lithomelissa setosa abundance and radiolarian absolute abundance are observed, whereas the benthic foraminiferal $\delta^{18} \mathrm{O}$ curve does not show such variability (Fig. 7). During the past $1500 \mathrm{kyr}$, the climate at high latitudes of the Northern Hemisphere was influenced by millennial-scale D-O events (e.g., Bond et al. 1993; Dansgaard et al. 1993, Hodell et al. 2016; Tada et al. 2018). These high-latitude climate changes likely affected the EASM and paleoceanography of seas adjacent to Asia, such as the Sea of Japan, by influencing the path of the westerly jet (e.g., Tada et al. 1999; Tada 2004; Itaki et al. 2007; Kido et al. 2007; Nagashima et al. 2007, 2011; Ikehara and Oshima 2009). As argued by Oba et al. (1991) and Tada et al. (1999), the ECS is the only source of the surface water in the Sea of Japan. Therefore, the high variability in $L$. setosa abundance and radiolarian absolute abundance recorded at site U1429 was probably related to the influence of D-O events, but our sampling interval precludes further discussion here.

The MIS 8 glacial period stands out as different from other glacial periods during the past $400 \mathrm{kyr}$. Indeed, although coastal species dominated during other glacial periods, during MIS 8, continental shelf species (A. calvata and Pseudocubus obeliscus) and KC species showed high abundances during the later and earlier parts of the stage, respectively (Fig. 7). During early MIS 8 , the benthic foraminiferal $\delta^{18} \mathrm{O}$ values were close to those of MIS 5 (Sagawa et al. 2018), suggesting that early MIS 8 
was distinguished by warmer deep water, a smaller sea-level drop, or both (Fig. 8). Indeed, the estimates of Elderfield et al. (2012) also imply a relatively smaller glacio-eustatic sea-level drop during MIS 8; thus, it is probable that the warming recorded during early MIS 8 in the northern ECS was related to the sea level being slightly higher than during other glaciations. The causes of this higher sea level are not understood at this time. In other areas, unexpected warming was recorded for the northern Japan Pacific coastal areas (off the Shimokita Peninsula) based on radiolarian data (Matsuzaki et al. 2014a), whereas the time interval corresponding to MIS 8 is missing (hiatus) from sediment cores retrieved at sites C0001 and C0002 during IODP Expedition 315 on the Pacific side of the Honshu Island coast off the Kii Peninsula, Japan (Matsuzaki et al. 2015b). In the Northwest Pacific (Shatsky Rise ODP Site 1209), calcareous nannofossil data suggest an increase in primary productivity during MISs 8-12 (Bordiga et al. 2013). Additionally, planktic foraminiferal and calcareous nannofossil data suggest that a modern water-mass structure was established in the Northwest Pacific (Shatsky Rise ODP 1210) at ca. 300 ka (MIS 8; Chiyonobu et al. 2012). Therefore, MIS 8 appears to have been different from other glacial maxima, but this difference cannot currently be explained based on our data and other available multi-proxy data available for this stage.

\section{Evolution of local primary productivity and its consequences for bottom water}

Evolution of local primary productivity based on radiolarians

Ocean acidification can drastically affect biomineralization by calcareous micro-organisms (e.g., Kawahata et al. 2018), but such effects are not well understood for polycystine radiolarians. Indeed, we just know that the skeletons of polycystine radiolarians are composed of amorphous (opaline) silica, and undersaturation of opal in sea water causes opal to dissolve at the seafloor (e.g., Takahashi 1981). These observations imply that the absolute abundance of radiolarians in sediment is affected by changes in both primary productivity and dissolution at the seafloor. At Site U1429, the preservation of radiolarian skeletons has been reported to be moderate to good (Tada et al. 2015), which was confirmed by our observations. Specifically, no signs of strong dissolution were recognized because most species were identifiable and only slight damage to individual specimens was observed. Such minor changes in radiolarian preservation may be related to changes in sedimentation rates because at Site U1429 the sedimentation rates varied from 30 to $40 \mathrm{~cm} / \mathrm{kyr}$ during interglacial periods to ca. 60 $80 \mathrm{~cm} / \mathrm{kyr}$ during glacial periods (Sagawa et al. 2018). Therefore, we assume that dissolution is not the main factor regulating radiolarian absolute abundances. In addition, most of the radiolarian species inhabiting shallow water in tropical to subtropical areas of the NW Pacific bear algal symbionts (Suzuki and Not 2015; Zhang et al. 2018). This fact suggests that radiolarians contribute, in part, to primary ocean productivity, at least in warm areas (De Wever et al. 2001; Suzuki and Not 2015; Zhang et al. 2018). In Fig. 9, we plotted total radiolarian absolute abundances and absolute abundances of species bearing algal symbionts following Zhang et al. (2018). Both curves fluctuate in a similar manner, suggesting that radiolarian absolute abundance is likely related to ocean primary productivity, at least in warm areas. Additionally, modern observations have indicated that the maximum radiolarian standing stock occurs at the water depths in which the chlorophyll- $a$ concentration is at a maximum (e.g., Kling 1979; Matsuzaki et al. 2016).

However, there is a discrepancy between radiolarian abundance and other primary productivity indicators such as total organic carbon (TOC \%) and diatom abundance (Tada et al. 2015; Fig. 9). The TOC and diatom data show that primary productivity at this site did not alter in association with glacial and interglacial cycles; instead, the primary productivity seems to have changed during the time interval between 130 to $220 \mathrm{ka}$ (Fig. 9). This discrepancy can be explained by considering that two factors control ocean primary productivity: sunlight and nutrients. Radiolarians related to the KC bear algal symbionts because they inhabit oligotrophic waters and thus have to obtain energy from photosynthesis. This fact explains why the absolute abundances of algal-symbiont-bearing radiolarians were higher during interglacial periods, and suggests that the absolute abundances of algal-symbiont-bearing species can be used as a primary productivity index for interglacial periods. However, this index cannot be used to compare primary productivity between interglacial and glacial periods. Indeed, our data show that the $\mathrm{KC}$ did not influence our site during glacial periods; thus, the absolute abundances of algal-symbiont-bearing species decreased. In contrast, the percentage abundances of coastal species increased during glacial periods because of the sea-level drop and consequent southeastward migration of the coastlines and river mouths of the main Chinese rivers, which might have led to a marked increase in the nutrient levels in shallow water. This finding indicates that, although we detected a drastic decrease in the abundances of species that bear algal symbionts, high nutrient levels were available in the shallow water during glacial periods, and thus the ocean primary productivity should have been also high during those times. Therefore, to compare and discuss changes in ocean primary productivity during glacial periods, abundances of coastal species (such as Lithomelissa setosa) should be used. 


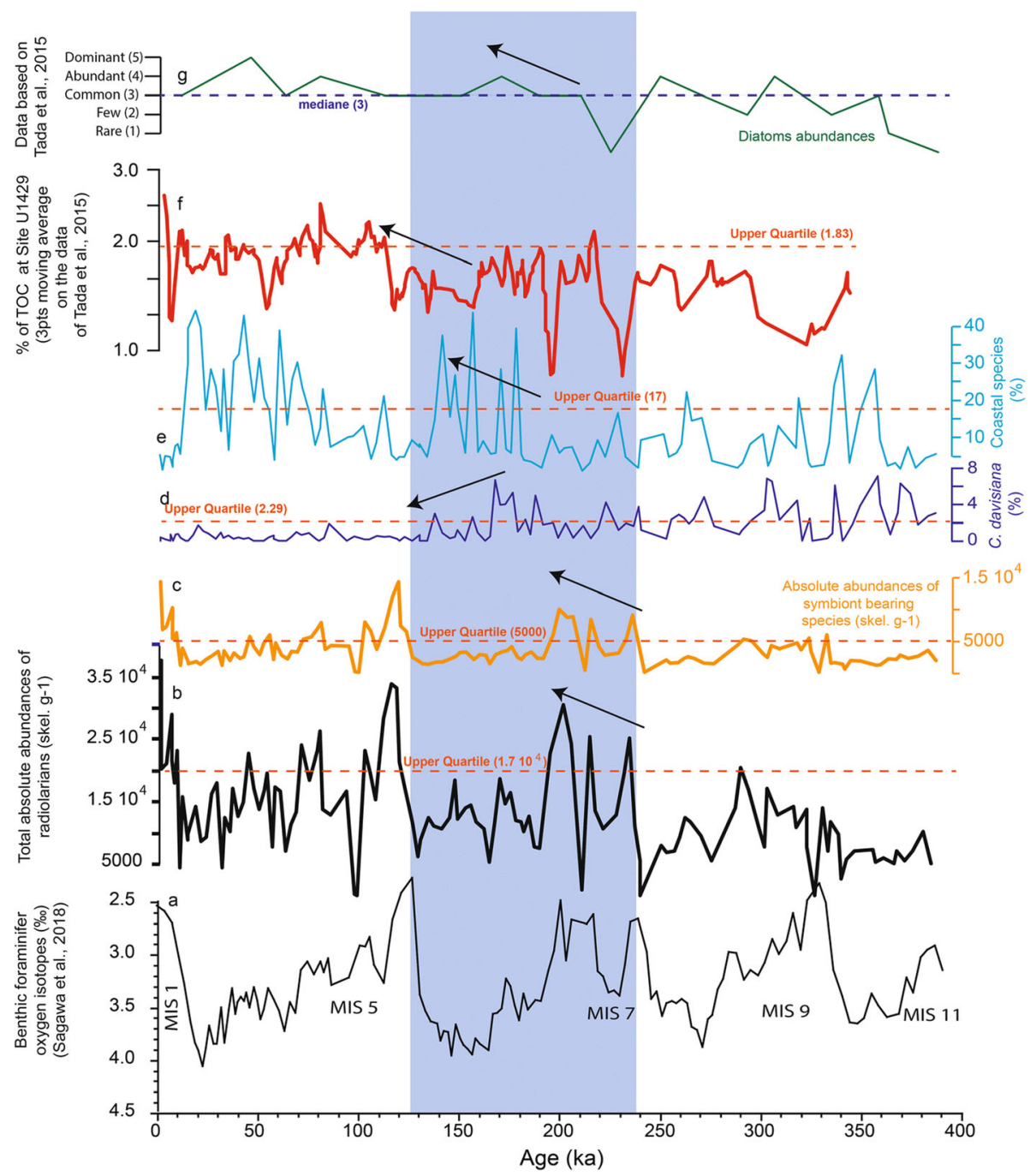

Fig. 9 Temporal fluctuation of the local primary productivity: a benthic foraminifera isotope curve of Sagawa et al. (2018), b radiolarian absolute abundance, c radiolarian absolute abundance of species bearing algal symbiosis based on Zhang et al. 2018 (A. vinculata, B. scutum, L. hispida, P. obeliscus, P. praetextum, P. clausus, A. lappacea/spinosa, D. tetrathalamus, D. muelleri, P. pylonium group, S. resurgens, S. streptacantha, Tetrapyle circularis/fruticosa group, L. reticulata, Heliodiscus spp., D. elegans), d C. davisiana (\%), e continental shelf species (\%), f total organic carbon (TOC) $(\%)$, and $\mathbf{g}$ diatom abundances

In this context, the absolute abundance of radiolarians that bear algal symbionts indicate higher primary productivity for the interglacial periods MISs 1,5 , and 7 , but not MISs 9 and 11 (Fig. 9). In contrast, the abundances of coastal species were higher during MISs 2-4 and 6 than during MIS 8 and 10 (Fig. 9). Combining both types of radiolarian data, our results suggest an increase in local primary productivity from the MIS 6 to MIS 7 (130-220 ka). The data on TOC (\%) and diatom abundances of Tada et al. (2015) suggest a similar trend, with a higher TOC (\%) around late MIS 6 and an increase in diatom abundance during early MIS 7 (Fig. 9).

The increases in primary productivity during MISs 24 and 6 are difficult to explain, but the amplitude of sea-level drop and/or changes in wind intensity may have been the cause(s). In contrast, the increase in primary productivity during interglacial periods is probably related to KC dynamics. Previous studies showed that the productivity and nutrient content of the northern ECS are controlled by upwelling of the KC subsurface water on the slope of the ECS continental shelf because this subsurface water is rich in nutrients such as nitrate (Wong et al. 1991; Chen and Wang 1999; Chen et al. 1999). Although the mechanism causing upwelling of KC subsurface water is debated, Chen and Wang (1999) and Chen (2000) suggested that advection of freshwater discharged from rivers by estuarine circulation allowed KC subsurface water to well up to the shelf. This 
upwelling supplied nutrients to the continental shelf of the ECS, which increased the local primary productivity (e.g., Chen 1996; Chen et al. 1999). Therefore, we hypothesize that local productivity may have been lower during MIS 9 than in later interglacial periods because of weaker upwelling of $\mathrm{KC}$ subsurface water at the slope of the ECS.

\section{Primary productivity and changes in intermediate water oxygenation}

The intermediate water of the ECS was probably less sensitive than the shallow water to the glacio-eustatic sea-level changes forced by orbital parameters. The reconstructed intermediate water temperature at ca. $500 \mathrm{~m}$ was apparently lower for the time interval from mid-MIS 6 to MIS 11 (>160 ka) compared to later MISs (Fig. 6). This finding is based on the occurrence of Cycladophora davisiana, which had a relative abundance of $5 \%$ or more of the total assemblage between mid-MIS 6 and MIS 11, whereas for the interval between MIS 1 and mid-MIS 6, its relative abundance was approximately $0 \%$ (Figs. 5 and 9).

Previous studies demonstrated that Cycladophora davisiana dominates the radiolarian assemblage of the Okhotsk Sea Intermediate Water (OSIW), which has cold, oxygen-rich water masses (Okazaki et al. 2003, 2004; Hays and Morley 2004; Itaki and Ikehara 2004;
Abelmann and Nimmergut 2005; Matul 2011). In the North Pacific, $C$. davisiana dominates assemblages in areas where the NPIW is formed (young NPIW), particularly in the northern Japan Oyashio area, where the OSIW mixes with water of the North Pacific (Talley 1993; Yasuda 1997, 2004; Okazaki et al. 2003; Itaki and Ikehara 2004; Abelmann and Nimmergut 2005; Itaki et al. 2009; Matul 2011; Matsuzaki et al. 2014b; Matsuzaki and Itaki 2017). In other areas of the North Pacific, particularly at middle to low latitudes, the relative abundance of $C$. davisiana is much lower, even in areas influenced by the NPIW (e.g., Boltovskoy and Riedel 1987; Kling and Boltovskoy 1995; Matsuzaki and Itaki 2017). Therefore, we can assume that $C$. davisiana is abundant in areas directly and/or indirectly influenced by the OSIW and that this species is related to cold, oxygen-rich water masses. In addition, based on studies conducted in the modern ECS, $C$. davisiana generally inhabits water depths below $500 \mathrm{~m}$, although its abundance is low (<1.5\%; Fig. 10; Matsuzaki and Itaki 2017). Therefore, we can infer that, as our site is ca. $730 \mathrm{~m}$ below present-day sea level, the abundance of $C$. davisiana is indicative of the bottom-water environmental conditions. Therefore, our data imply that the bottom water was moderately oxygenated and relatively cold between 160 and $400 \mathrm{ka}$, whereas after

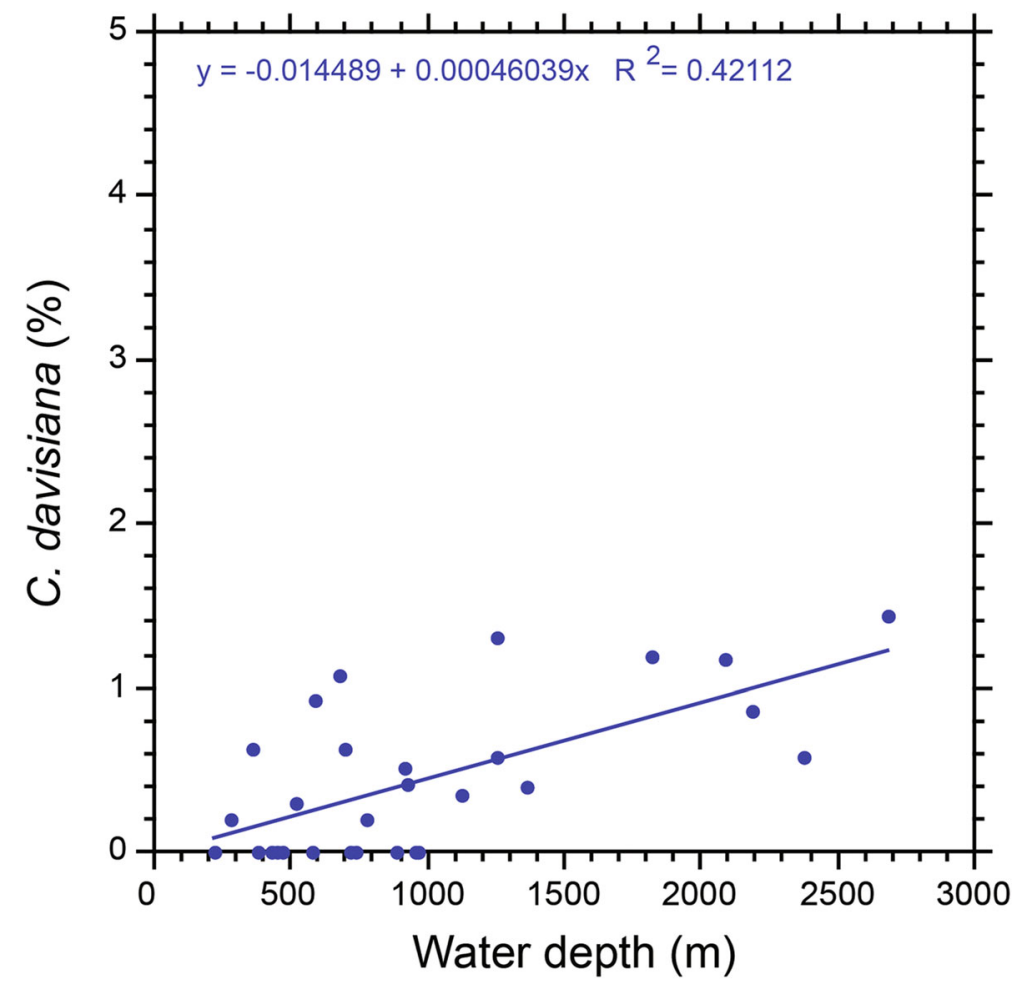

Fig. 10 Current vertical distribution of C. davisiana in the ECS based on the dataset of Matsuzaki and Itaki (2017) 
than $160 \mathrm{ka}$, the bottom water was oxygen-poorer and also probably warmer (Fig. 7).

Changes in Cycladophora davisiana abundance cannot be explained by plausible changes in the NPIW influence, because the NPIW is characterized by low oxygen content in the ECS, and C. davisiana prefers an oxygen-rich environment (e.g., Kaneko et al. 2001). Thus, we attribute changes in bottom-water oxygenation to local factors. Indeed, from our data and other onboard data of Tada et al. (2015) discussed above, the time interval between MIS 1 and MIS 7 (0-220 ka) was probably characterized by higher primary productivity in shallow waters (Fig. 9). This finding implies that the deep-sea sediments collected from site U1429 became richer in organic carbon after $220 \mathrm{ka}$ (Fig. 9). Therefore, it is likely that the inferred increase in the primary productivity of shallow waters during MIS 6 and MIS 7 enhanced the production of organic matter (carbon), which sank to the sea bottom and increased the amount of organic carbon in deep-sea sediments. This organic carbon accumulated at the seafloor and was oxidized, which consumed the available oxygen at these depths (e.g., Ruddiman 2001). Therefore, an increase in the shallow-water productivity reduced the amount of available oxygen in the bottom water and thus decreased the bottom-water oxygenation, which probably caused the lowering of $C$. davisiana abundance.

\section{Conclusions}

Analysis of radiolarian assemblages collected from Site U1429 enabled us to reconstruct the paleoceanographic history of the northern ECS over the last 400,000 years. We conclude that radiolarians in the ECS were sensitive to environmental changes caused by glacio-eustatic sea-level variations and regional climatic events in the following ways.

1. Although the similarity of radiolarian assemblages for MISs 1, 5, 7, and 9 suggests that the modern KC flow was not significantly altered during previous interglacial periods, during MIS 1 and MIS 5 our data implies that the KC influenced the ECS after the sea level had risen. The radiolarian assemblages suggest that the shelf water of the ECS probably influenced the study site during sea-level maxima. This effect was probably related to the high solar insolation at $65^{\circ} \mathrm{N}$ during those times and probable intensification of the EASM, which intensified freshwater discharge into the ECS.

2. During glacial periods (MISs $2-4,6$, and 10 ), because of a sea-level drop of ca. $90 \mathrm{~m}$, the ECS continental shelf emerged. In this context, our radiolarian assemblages imply that coastal conditions prevailed at site U1429, although MIS 10 was probably warmer.
Additionally, our data suggest that the shallow water was likely rich in nutrients due to injection of lithogenic matter into the shallow water precipiltated by eastward migration of the Chinese coastline.

3. The intermediate water temperature at a water depth of ca. $500 \mathrm{~m}$ reconstructed from our radiolarian assemblages fluctuated roughly synchronously with the interglacial-glacial period cycle between 0 and $130 \mathrm{ka}$ (MIS 5/6 boundary). For older periods, the water temperature at ca. $500 \mathrm{~m}$ was probably not related to these cycles.

4. The data on radiolarian assemblages suggest that the bottom-water oxygenation changed at site U1429 around $160 \mathrm{ka}$. Oxygen-poor conditions appear to have prevailed after mid-MIS 6 (ca. 160 kyr), whereas the interval between mid-MIS 6 and MIS 11 was relatively richer in oxygen. This change was probably caused by increased shallow-water productivity, which resulted in larger amounts of sinking organic matter; oxidation of this additional organic matter led to increased oxygen consumption.

\section{Additional files}

Additional file 1: Counts of radiolarians species at Site U1429 (IODP 346). (XLSX $118 \mathrm{~kb}$ )

Additional file 2: Table S1. Relative abundance (\%) of selected shallow water species after the normalization of Matsuzaki and Itaki (2017) to estimate the paleo-summer SST at site U1429 (PDF 37 kb)

Additional file 3: Table S2. Relative abundance (\%) of selected intermediate water species after the normalization of Matsuzaki and Itaki (2017) to estimate the paleo intermediate water temperature at ca. $500 \mathrm{~m}$ at site U1429 (PDF $32 \mathrm{~kb}$ )

Additional file 4: Table S3. Reconstructed paleo-summer SST and intermediate water temperature at ca. $500 \mathrm{~m}$ at site U1429 with margins of error (PDF $21 \mathrm{~kb}$ )

\section{Abbreviations}

CCSF-D: Core composite depth below sea floor; CDW: Changjiang river diluted water; CSW: Continental shelf water; D-O events: DansgaardOeschger events; EASM: East Asian summer monsoon; ECS: East China Sea; IODP: Integrated Ocean Drilling Program; KC: Kuroshio Current; MIS: Marine isotopic stage; NPIW: North Pacific Intermediate Water; OSIW: Okhotsk Sea Intermediate Water; SSS: Sea surface salinity; SST: Sea surface temperature; TOC: Total organic carbon; TWC: Taiwan Warm Current

\section{Acknowledgments}

We would like to thank IODP Expedition 346 for providing us with the samples and the curators of the Kochi Core Center for their sampling assistance. We also wish to thank Dr. Li Lo (Guangzhou Institute of Geochemistry) and Dr. Tomohisa Irino (Hokkaido University) for helpful advice. Lastly, we wish to thank two anonymous reviewers for helpful comments, advice, and criticisms which helped to improve our manuscript significantly.

\section{Funding}

This research was financially supported by the Japan Society for the Promotion of Science (JSPS) Grant-in-Aid for Young Scientists (B), number 15 K17782 awarded to MKM. This work was also partially financed by IODP Exp. 346 After Cruise Research Program, JAMSTEC awarded IT and JSPS KAKENHI Grant Number $16 \mathrm{H} 04069$ to Yusuke Okazaki (Kyushu University). 


\section{Availability of data and materials}

The radiolarian data used in this study are available in the appendix, which is attached to this study as supplementary material.

\section{Competing interests}

The authors declare that they have no competing interest.

\section{Authors' contributions}

MKM conducted treatment and analysis on 124 samples from Site U1429, drew figures, tables, interpreted the data, and wrote the manuscript. IT and TR assisted with data interpretation, proposed the topic, and designed the study.

\section{Authors' information}

MKM is assistant professor at the University of Tokyo; IT is a senior researcher at the Geological Survey of Japan, AIST; and TR is a professor of the University of Tokyo and was the host researcher of MKM until 2018.08 and the co-chief of IODP Exp. 346.

\section{Publisher's Note}

Springer Nature remains neutral with regard to jurisdictional claims in published maps and institutional affiliations.

\section{Author details}

'Department of Earth and Planetary Science, Graduate School of Science, The University of Tokyo, 7-3-1, Hongo, Bunkyo-ku, Tokyo 113-0033, Japan. ${ }^{2}$ Present address: Atmosphere and Ocean Research Institute, The University of Tokyo, 5-1-5 Kashiwanoha, Kashiwa, Chiba 277-8564, Japan. ${ }^{3}$ Geological Survey of Japan, AIST, Marine Geology Research Group/Institute of Geology and Geoinformation, Tsukuba Central 7, 1-1-1 Higashi, Tsukuba, Ibaraki 305-8567, Japan.

Received: 11 March 2018 Accepted: 7 January 2019

Published online: 20 February 2019

\section{References}

Abelmann A, Nimmergut A (2005) Radiolarians in the Sea of Okhotsk and their ecological implication for paleoenvironmental reconstructions. Deep-Sea Res II Top Stud Oceanogr 52(16):2302-2331

Beardsley RC, Limeburner R, Yu H, Cannon GA (1985) Discharge of the Changjiang (Yangtze River) into the East China Sea. Cont Shelf Res 4:57-76

Berger WH, Jansen E (1994) Mid-Pleistocene climate shift - the Nansen connection, in: O.M. Johannessen, R.D. Muench, J.E. Overland (Eds), The Polar Oceans and Their Role in Shaping the Global Environment. Am Geophys Union Geo-phys Monogr 85:295-311

BjÖrklund KR (1974) The seasonal occurrence and depth zonation of radiolarians in Korsfjorden, western Norway. Sarsia 56(1):13-42

Boltovskoy D, Correa N (2016) Biogeography of Radiolaria Polycystina (Protista) in the World Ocean. Prog Oceanogr 149:82-105 https://doi.org/10.1016/j. pocean.2016.09.006

Boltovskoy D, Riedel WR (1987) Polycystine radiolaria of the California current region: seasonal and geographic patterns. Mar Micropaleontol 12:65-104

Boltovskoy DE, Kling SA, Takahashi K, Bjørklund K (2010) World atlas of distribution of recent Polycystina. Paleontol Electron 13:1-229 http://palaeoelectronica.org/2010_3/215/index.html

Bond G, Broecker W, Johnsen S, McManus J, Labeyrie L, Jouzel J, Bonani G (1993) Correlations between climate records from North Atlantic sediments and Greenland ice. Nature 365(6442):143-147

Bordiga M, Beaufort L, Cobianchi M, Lupi C, Mancin N, Luciani V et al (2013) Calcareous plankton and geochemistry from the ODP site 1209B in the NW Pacific Ocean (Shatsky Rise): new data to interpret calcite dissolution and paleoproductivity changes of the last 450ka. Palaeogeogr Palaeoclimatol Palaeoecol 371:93-108

Bostock HC, Opdyke BN, Williams MJM (2010) Characteriz- ing the intermediate depth waters of the Pacific Ocean using $813 \mathrm{C}$ and other geochemical tracers. Deep-Sea Res Pt I 57:847-859

Chen C, Beardsley RC, Limeburner R, Kim K (1994) Comparison of winter and summer hydrographic observations in the Yellow and East China seas and adjacent Kuroshio during 1986. Cont Shelf Res 14:909-928

Chen CTA (1996) The Kuroshio intermediate water is the major source of nutrients on the East China Sea continental shelf. Oceanol Acta 19(5):523-527
Chen CTA (2000) The Three Gorges dam: reducing the upwelling and thus productivity in the East China Sea. Geophys Res Lett 27(3):381-383

Chen YLL, Lu HB, Shiah FK, Gong GC, Liu KK, Kanda J (1999) New production and f-ratio on the continental shelf of the East China Sea: comparisons between nitrate inputs from the subsurface Kuroshio current and the Changjiang River. Estuar Coast Shelf Sci 48(1):59-75.

Chen CTA, Wang SL (1999) Carbon, alkalinity and nutrient budgets on the East China Sea continental shelf. J Geophys Res Oceans 104(C9):20675-20686

Chiyonobu S, Mori Y, Oda M (2012) Reconstruction of paleoceanographic conditions in the northwestern Pacific Ocean over the last 500kyr based on calcareous nannofossil and planktic foraminiferal assemblages. Mar Micropaleontol 96:29-37

Dansgaard W, Johnsen SJ, Clausen HB, Dahl-Jensen D, Gundestrup NS, Hammer $\mathrm{CU}$ et al (1993) Evidence for general instability of past climate from a 250-kyr ice-core record. Nature 364(6434):218-220

De Wever P, Dumitrica P, Caulet JP, Nigrini C, Caridroit M (2001) Radiolarians in the sedimentary record. Gordon and Breach Science Publishers, Amsterdam, p 533

Elderfield H, Ferretti P, Greaves M, Crowhurst S, McCave IN, Hodell DA, Piotrowski AM (2012) Evolution of ocean temperature and ice volume through the midPleistocene climate transition. Science 337(6095):704-709

Fairbanks RG, Wiebe PH (1980) Foraminifera and chlorophyll maximum: vertical distribution, seasonal succession, and paleoceanographic significance. Science 209(4464):1524-1526

Gooday AJ (2003) Benthic foraminifera (Protista) as tools in deep-water palaeoceanography: environmental influences on faunal characteristics. Adv Mar Biol 46:1-90

Hammer O, Harper D, Ryan PD (2001) PAST: paleontological statistic software package for education and data analyses. Paleontol Eletrôn 4:9

Harper DAT (ed) (1999) Numerical Palaeobiology. Computer-Based Modelling and Analysis of Fossils and their Distributions. Chichester, New York, p 468

Hays JD, Imbrie J, Shackleton NJ (1976) Variations in the Earth's orbit: pacemaker of the ice ages. Science 194(4270):1121-1132

Hays JD, Morley JJ (2004) The Sea of Okhotsk: a window on the ice age ocean. Deep-Sea Res I Oceanogr Res Pap 51(4):593-618

Hernández-Almeida I, Cortese G, Yu PS, Chen MT, Kucera M (2017) Environmental determinants of radiolarian assemblages in the western Pacific since the last deglaciation. Paleoceanography 32:830-847. https:// doi.org/10.1002/2017PA003159

Hodell DA, Channell JET (2016) Mode transitions in northern hemisphere glaciation: co-evolution of millennial and orbital variability in quaternary climate. Clim Past 12:1805-1828

Hodell DA, Hernández-Molina FJ, Stow DA, Alvarez-Zarikian C (2016) Virtual special issue on IODP Expedition 339: The Mediterranean outflow. Glob Planet Chang 144:263-269

Horikawa K, Kodaira T, Zhang J, Murayama M (2015) $\delta$ Osw estimate for Globigerinoides ruber from core-top sediments in the East China Sea. Prog Earth Planet Sci 2(19) https://doi.org/10.1186/s40645-015-0048-3

Huh CA, Su CC (1999) Sedimentation dynamics in the East China Sea elucidated from 210Pb, 137Cs and 239,240 Pu Mar Geol 160(1):183-196

Ichikawa H, Beardsley RC (2002) Review: the current system in the yellow and East China seas. J Oceanogr 58(1):77-92

ljiri A, Wang L, Oba T, Kawahata H, Huang CY, Huang CY (2005) Paleoenvironmental changes in the northern area of the East China Sea during the past 42,000 years. Palaeogeogr Palaeoclimatol Palaeoecol 219(3):239-261

Ikehara K, Oshima H (2009) Orbital-and millennial-scale fluctuations in late Quaternary marine pollen records from the Japan Sea. J Quat Sci 24(8):866-879

Imbrie J, Kipp NG (1971) A new micropaleontological method for paleoclimatology: application to a Late Pleistocene Caribbean core. In: Turekian KK (ed) The late Cenozoic glacial ages. Yale University Press, New Haven, pp 71-181

Irino T, Tada R, Ikehara K, Sagawa T, Karasuda A, Kurokawa S, Seki A, Lu S (2018) Construction of perfectly continuous records of physical properties for darklight sediment sequences collected from the Japan Sea during Integrated Ocean Drilling Program Expedition 346 and their potential utilities as paleoceanographic studies. Prog Earth Planet Sci 5(1):23 https://doi.org/10. 1186/s40645-018-0176-7

Isobe A, Matsuno T (2008) Long-distance nutrient-transport process in the Changjiang river plume on the East China Sea shelf in sum- mer. J Geophys Res 113:C04006 https://doi.org/10.1029/2007jc004248

Itaki T (2004) Radiolarian assemblages in plankton and surface sediment materials from the Oyashio area obtained during GH03 cruise. Marine geological and geophysical study on the collision zone of Kurile and Northeast Japan-off 
Kushiro and Hidaka area-preliminary reports on researches in the 2003 Fiscal Year, GSJ Interim Report. Geol Surv Jpn 30:104-111

Itaki T (2009) Last Glacial to Holocene polycystine radiolarians from the Japan Sea. News Osaka Micropaleontol (NOM) 14:43-89

Itaki T, Ikehara K (2004) Middle to late Holocene changes of the Okhotsk Sea intermediate water and their relation to atmospheric circulation. Geophys Res Lett 31(24):L24309. https://doi.org/10.1029/2004GL021384

Itaki T, Ikehara K, Motoyama I, Hasegawa S (2004) Abrupt ventilation changes in the Japan Sea over the last 30 ky: evidence from deep-dwelling radiolarians. Palaeogeogr Palaeoclimatol Palaeoecol 208(3):263-278

Itaki T, Kimoto K, Hasegawa S (2010) Polycystine radiolarians in the Tsushima Strait in autumn of 2006. Paleontol Res 14(1):19-32

Itaki T, Komatsu N, Motoyama I (2007) Orbital-and millennial-scale changes of radiolarian assemblages during the last 220 kyrs in the Japan Sea. Palaeogeogr Palaeoclimatol Palaeoecol 247(1):115-130

Itaki T, Minoshima K, Kawahata H (2008) Radiolarian flux at an IMAGES site at the western margin of the subarctic Pacific and its seasonal relationship to the Oyashio cold and Tsugaru warm currents. Mar Geol 255(3):131-148

Itaki T, Uchida M, Kim S, Shin HS, Tada R, Khim BK (2009) Late Pleistocene stratigraphy and palaeoceanographic implications in northern Bering Sea slope sediments: evidence from the radiolarian species Cycladophora davisiana. J Quat Sci 24(8):856-865

Itaki T (2016) Transitional changes in microfossil assemblages in the Japan Sea from the Late Pliocene to Early Pleistocene related to global climatic and local tectonic events. Prog Earth Planet Sci 3(1)

Ito T, Kaneko A, Tsubota H, Gohda N (1994) The characteristic distribution of silica over the East China Sea shelf slope. J Oceanogr 50(4):465-477

Kagimoto T, Yamagata T (1997) Seasonal transport variations of the Kuroshio: an OGCM simulation. J Phys Oceanogr 27:403-418. https://doi.org/10.1175/15200485(1997)027b0403:STVOTKN2.0.CO;2

Kamikuri S, Nishi H, Motoyama I (2007) Effects of late Neogene climatic cooling on North Pacific radiolarian assemblage and oceanographic conditions. Palaeogeogr Palaeoclimatol Palaeoecol 249:370-392 https://doi.org/10.1016/j. palaeo.2007.02.008

Kamikuri SI, Motoyama I, Nishimura A (2008) Radiolarian assemblages in surface sediments along longitude $175 \mathrm{E}$ in the Pacific Ocean. Mar Micropaleontol 69(2):151-172

Kaneko I, Takatsuki Y, Kamiya H (2001) Circulation of intermediate and deep waters in the Philippine Sea. J Oceanogr 57:397-420

Kawahata H, Fujita K, Iguchi A, Inoue M, Iwasaki S, Kuroyanagi A, Maeda A, Manaka T, Moriya K, Takagi H, Toyofuku T, Yoshimura T, Suzuki A (2019) Perspective of the response by marine calcifiers to global warming and ocean acidification-behavior of corals and foraminifers in the high CO2 world in "hot house". Prog Earth Planet Sci 2019.6:5. https://doi.org/10.1186/s40645-018-0239-9

Kawahata H, Ohshima H (2004) Vegetation and environmental record in the northern East China Sea during the late Pleistocene. Glob Planet Chang 41(3):251-273

Kido Y, Minami I, Tada R, Fujine K, Irino T, Ikehara K, Chun JH (2007) Orbital-scale stratigraphy and highresolution analysis of biogenic components and deepwater oxygenation conditions in the Japan Sea during the last $640 \mathrm{kyr}$. Palaeogeogr Palaeoclimatol Palaeoecol 247(1):32-49

Kling SA (1979) Vertical distribution of polycystine radiolarians in the central North Pacific. Mar Micropaleontol 4:295-318

Kling SA, Boltovskoy D (1995) Radiolarian vertical distribution patterns across the southern California current. Deep-Sea Res I Oceanogr Res Pap 42(2):191-231

Kubota Y, Kimoto K, Itaki T, Yokoyama Y, Miyairi Y, Matsuzaki H (2015b) Bottom water variability in the subtropical northwestern Pacific from $26 \mathrm{kyr}$ BP to present based on $\mathrm{Mg} / \mathrm{Ca}$ and stable carbon and oxygen isotopes of benthic foraminifera. Clim Past 11(6):803-824

Kubota Y, Kimoto K, Tada R, Oda H, Yokoyama Y, Matsuzaki H (2010) Variations of East Asian summer monsoon since the last deglaciation based on Mg/Ca and oxygen isotope of planktic foraminifera in the northern East China Sea. Paleoceanography 25:PA4205. https://doi.org/10.1029/2009PA001891

Kubota Y, Tada R, Kimoto K (2015a) Changes in East Asian summer monsoon precipitation during the Holocene deduced from a freshwater flux reconstruction of the Changjiang (Yangtze River) based on the oxygen isotope mass balance in the northern East China Sea. Clim Past 11(2):265

Kuroyanagi A, Kawahata H (2004) Vertical distribution of living planktonic foraminifera in the seas around Japan. Mar Micropaleontol 53(1):173-196
Lee TN, Johns WE, Liu CT, Zhang D, Zantopp R, Yang Y (2001) Mean transport and seasonal cycle of the Kuroshio east of Taiwan with comparison to the Florida current. J Geophys Res 106(22):143-158 https://doi.org/10.1029/2000JC000535

Lisiecki LE, Raymo ME (2005) A Pliocene-Pleistocene stack of 57 globally distributed benthic $\delta 180$ records. Paleoceanography 20:PA1003. https://doi. org/10.1029/2004PA001071

Locarnini RA et al (2013) World Ocean Atlas 2013, Volume 1: Temperature (S. Levitus, ed., A Mishonov, technical ed.): National Oceanic and Atmospheric Administration (NOAA) At- las NESDIS 73, p 40 publication https:/doi.org/ 110.7289/N55X26VD, dataset https://doi.org/110.7289/N5F769GT

Lombari G, Boden G (1985) Modern radiolarian global distributions. Cushman Found Foraminiferal Res Spec Publ 16A:68-69

Matsuno T, Lee JS, Yanao S (2009) The Kuroshio exchange with the South and East China seas. Ocean Sci 5(3):303-312

Matsuzaki KM, Itaki T (2017) New northwest Pacific radiolarian data as a tool to estimate past sea surface and intermediate water temperatures. Paleoceanography 32(3):218-245

Matsuzaki KM, Itaki T, Kimoto K (2016) Vertical distribution of polycystine radiolarians in the northern East China Sea. Mar Micropaleontol 125:66-84

Matsuzaki KM, Itaki T, Tada R, Kamkikuri SI (2018) Paleoceanographic history of the Japan Sea over the last 9.5 million years inferred from radiolarian assemblages (IODP expedition 346 sites U1425 and U1430). Prog Earth Planet Sci 5:54 https://doi.org/10.1186/s40645-018-0204-7

Matsuzaki KM, Nishi H, Suzuki N, Cortese G, Eynaud F, Takashima R, Sakai T (2014a) Paleoceanographic history of the Northwest Pacific Ocean over the past 740kyr, discerned from radiolarian fauna. Palaeogeogr Palaeoclimatol Palaeoecol 396:26-40

Matsuzaki KM, Nishi H, Suzuki N, Kawate Y, Takashima R, Sakai T (2014b) Cycladophora davisiana abundances as a paleoceanographic and stratigraphic tool in high latitude siliciceous sediments. Mar Micropaleontol 106:1-9

Matsuzaki KM, Suzuki N, Nishi H (2015a) Middle to Upper Pleistocene polycystine radiolarians from hole 902-C9001C, northwestern Pacific. Paleontol Res 19(s1):1-77

Matsuzaki KM, Suzuki N, Nishi H, Hayashi H, Gyawali BR, Takashima R, Ikehara M (2015b) Early to Middle Pleistocene paleoceanographic history of southern Japan based on radiolarian data from IODP Exp. 314/315 sites C0001 and C0002. Mar Micropaleontol 118:17-33

Matul AG (2011) The recent and quaternary distribution of the radiolarian species Cycladophora davisiana: a biostratigraphic and paleoceanographic tool. Oceanology 51(2):335-346

Motoyama I., Nishimura A (2005) Distribution of radiolarians in the North Pacific surface sediments along the $175^{\circ} \mathrm{E}$ Meridian. Paleontol Res 9(2):95-117. https://doi.org/10.2517/prpsj.9.95.

Nagashima K, Tada R, Matsui H, Irino T, Tani A, Toyoda S (2007) Orbital-and millennial-scale variations in Asian dust transport path to the Japan Sea. Palaeogeogr Palaeoclimatol Palaeoecol 247(1-2):144-161

Nagashima K, Tada R, Tani A, Sun Y, Isozaki Y, Toyoda S, Hasegawa H (2011) Millennial-scale oscillations of the westerly jet path during the last glacial period. J Asian Earth Sci 40(6):1214-1220

Oba T, Kato M, Kitazato H, Koizumi I, Omura A, Sakai T, Takayama T (1991) Paleoenvironmental changes in the Japan Sea during the last 85,000 years. Paleoceanography 6(4):499-518

Okazaki Y, Takahashi K, Asahi H (2008) Temporal fluxes of radiolarians along the W-E transect in the central and western equatorial Pacific, 1999-2002. Micropaleontology 54:71-86

Okazaki Y, Takahashi K, Itaki T, Kawasaki Y (2004) Comparison of radiolarian vertical distributions in the Okhotsk Sea near the Kuril Islands and in the northwestern North Pacific off Hokkaido Island. Mar Micropaleontol 51(3):257-284

Okazaki Y, Takahashi K, Nakatsuka T, Honda MC (2003) The production scheme of Cycladophora davisiana (Radiolaria) in the Okhotsk Sea and the northwestern North Pacific: implication for the paleoceanographic conditions during the glacials in the high latitude oceans. Geophys Res Lett 30(18):1939. https://doi. org/10.1029/2003GL018070

Okazaki Y et al (2005) Late Quaternary paleoceanographic changes in the southwestern Okhotsk Sea: evidence from geochemical, radiolarian, and diatom records. Deep-Sea Res II Top Stud Oceanogr 52(16-18):2332-2350

Paillard D, Labeyrie L, Yiou P (1996) Macintosh program performs time-series analysis, Eos trans. AGU 77:379

Qu T, Lukas R (2003) The bifurcation of the north equatorial current in the Pacific. J Phys Oceanogr 33(1):5-18 
Ruddiman W (2001) Earth's climate: past and future, 1st edn. Macmillan, New York

Sagawa T, Nagahashi Y, Satoguchi Y, Holbourn A, Itaki T, Gallagher SJ, SaavedraPellitero M, Ikehara K, Irino T, Tada R (2018) Integrated tephrostratigraphy and stable isotope stratigraphy in the Japan Sea and East China Sea using IODP Sites U1426, U1427, and U1429, Expedition 346 Asian Monsoon. Prog Earth Planet Sci 5(1). https://doi.org/10.1186/s40645-018-0168-7

Shannon CE, Weaver W (1949) The mathematical theory of communication. University of Illinois Press, Urbana, pp 1-125

Shi X, Wu Y, Zou J, Liu Y, Ge S, Zhao M, Liu J, Zhu A, Meng X, Yao Z, Han Y (2014) Multiproxy reconstruction for Kuroshio responses to northern hemispheric oceanic climate and the Asian monsoon since marine isotope stage 5.1 ( $\sim 88$ ka). Clim Past 10:1735-1750 https://doi.org/10.5194/cp-10-1735-2014

Su CC, Huh CA (2002) 210 Pb, 137 Cs and 239,240 Pu in East China Sea sediments: sources, pathways and budgets of sediments and radionuclides. Mar Geol 183(1):163-178

Sun Y, Oppo DW, Xiang R, Liu W, Gao S (2005) Last deglaciation in the Okinawa trough: subtropical Northwest Pacific link to northern hemisphere and tropical climate. Paleoceanography 20:PA4005 https://doi.org/10.1029/ 2004PA001061

Suzuki N, Aita Y (2011) Radiolaria: achievements and unresolved issues: taxonomy and cytology. Plankton Benthos Res 6(2):69-91

Suzuki N, Not F (2015) Biology and ecology of Radiolaria. In: Marine Protists. Springer, Japan, pp 179-222

Tada R (2004) Onset and evolution of millennial-scale variability in the Asian monsoon and its impact on paleoceanography of the Japan Sea. Continentocean interactions within East Asian marginal seas, pp 283-298

Tada R, Irino T, Ikehara K, Karasuda A, Sugisaki S, Xuan C et al (2018) High-resolution and high-precision correlation of dark and light layers in the Quaternary hemipelagic sediments of the Japan Sea recovered during IODP Expedition 346. Prog Earth Planet Sci 5(1) https://doi.org/10.1186/s40645-018-0167-8

Tada R, Irino T, Koizumi I (1999) Land-ocean linkages over orbital and millennial timescales recorded in Late Quaternary sediments of the Japan Sea. Paleoceanography 14(2):236-247

Tada R, Murray RW, Alvarez Zarikian CA, Anderson WT Jr, BassettiM-A, Brace BJ, Clemens SC, da Costa Gurgel MH, Dickens GR, Dunlea AG, Gallagher SJ, Giosan L, Henderson ACG, Holbourn AE, Ikehara K, Irino T, Itaki T, Karasuda A, Kinsley CW, Kubota Y, Lee GS, Lee KE, Lofi J, Lopes CICD, Peterson LC, Saavedra-Pellitero M, Sagawa T, Singh RK, Sugisaki S, Toucanne S, Wan S, Xuan C, Zheng H, Ziegler M (2015) Sites U1428 and U1429. In Tada, R., Murray, R.W., Alvarez Zarikian, C.A., and the Expedition 346 scientists, Proc. IODP, 346: College Station, (Integrated Ocean drilling program). https://doi. org/10.2204/iodp.proc.346.109.2015

Tada R, Zheng H, Clift PD (2016) Evolution and variability of the Asian monsoon and its potential linkage with uplift of the Himalaya and Tibetan plateau. Prog Earth Planet Sci 3:4 https://doi.org/10.1186/s40645-016-0080-y

Takahashi K (1981) Vertical flux, ecology and dissolution of Radiolaria in tropical oceans: implications for the silica cycle (Doctoral dissertation, Massachusetts Institute of Technology and Woods Hole Oceanographic Institution). https:// doi.org/10.1575/1912/2420, https://hdl.handle.net/1912/2420

Talley LD (1993) Distribution and formation of North Pacific intermediate water. J Phys Oceanogr 23(3):517-537

Tian RC, Hu FX, Martin JM (1993) Summer nutrient fronts in the Changjiang (Yantze River) estuary. Estuar Coast Shelf Sci 37(1):27-41

Tomczak M, Godfrey JS (1994) Regional oceanography: an introduction. Pergamon Press, Oxford, pp 1-422

Ujiie H, Tanaka Y, Ono T (1991) Late Quarternary paleoceanographic record from the middle Ryukyu trench slope, Northwest Pacific. Mar Micropaleontol 18(12):115-128

Ujiié H, Ujiié Y (1999) Late Quaternary course changes of the Kuroshio current in the Ryukyu arc region, northwestern Pacific Ocean. Mar Micropaleontol 37(1):23-40

Wang Y, Cheng H, Edwards RL, Kong X, Shao X, Chen S et al (2008) Millennialand orbital-scale changes in the East Asian monsoon over the past 224,000 years. Nature 451(7182):1090-1093

Wang YJ, Cheng H, Edwards RL, An ZS, Wu JY, Shen CC, Dorale JA (2001) A highresolution absolute-dated late Pleistocene monsoon record from Hulu Cave, China. Science 294(5550):2345-2348

Wary M et al (2016) Norwegian Sea warm pulses during Dansgaard-Oeschger stadials: Zooming in on these anomalies over the 35-41 ka cal BP interval and their impacts on proximal European ice-sheet dynamics. Quat Sci Rev 151:255-272
Wong GT, Pai SC, Liu KK, Liu CT, Chen CTA (1991) Variability of the chemical hydrography at the frontal region between the East China Sea and the Kuroshio north-east of Taiwan. Estuar Coast Shelf Sci 33(2):105-120

Xie C, Jian Z, Zhao Q (1995) Paleogeographic maps of the China seas at the last glacial maximum. In: WESTPAC Paleogeographic Maps. UNESCO/IOC Publications, Shanghai, p 75

Xu X, Oda M (1999) Surface-water evolution of the eastern East China Sea during the last 36,000 years. Mar Geol 156(1):285-304

Yasuda I (1997) The origin of the North Pacific intermediate water. J Geophys Res 102:1165-1174

Yasuda I (2004) North Pacific intermediate water: Progress in SAGE (SubArctic gyre experiment) and related projects. J Oceanogr 60:385-395

Yokoyama Y, De Deckker P, Lambeck K, Johnston P, Fifield LK (2001) Sea-level at the last glacial maximum: evidence from northwestern Australia to constrain ice volumes for oxygen isotope stage 2. Palaeogeogr Palaeoclimatol Palaeoecol 165(3):281-297

Zhang L, Suzuki N (2017) Taxonomy and species diversity of Holocene pylonioid radiolarians from surface sediments of the northeastern Indian Ocean. Palaeontol Electron 20(3):1-68

Zhang L, Suzuki N, Nakamura Y, Tuji A (2018) Modern shallow water radiolarians with photosynthetic microbiota in the western North Pacific. Mar Micropaleontol 139:1-27

\section{Submit your manuscript to a SpringerOpen ${ }^{\circ}$ journal and benefit from:}

- Convenient online submission

- Rigorous peer review

- Open access: articles freely available online

- High visibility within the field

- Retaining the copyright to your article

Submit your next manuscript at $\boldsymbol{\nabla}$ springeropen.com 